Revista Portuguesa de História

t. XXXV (2001-2002)

\title{
A Indústria mineira em Portugal Continental desde a consolidação do regime liberal ao I Plano de Fomento do Estado Novo (1832-1953). Um esboço de caracterização
}

JOÃo PAUlO AVELÃS NUNES

Universidade de Coimbra

\begin{abstract}
"Durante muito tempo, os mineiros permaneceram os proletários arquétipos. Com as suas caras marcadas, os seus clubes ruidosos, as suas aldeias fechadas, as suas habitações estandartizadas, apresentam muitas das características geralmente associadas ao militante operário, puro e duro [...]. Mesmo em Portugal, onde a sua presença era indiscutivelmente menor, sempre que se tratava de apresentar alguma reportagem sobre os "miseráveis", os mineiros eram a escolha clássica. A historiografia portuguesa tem-se ocupado pouco das minas e dos mineiros. Praticamente nada se sabe sobre a evolução do sector ou as condições de vida."
\end{abstract}

1. Justificação e limites

Em acréscimo ao peso intrínseco do sector extractivo no contexto da evolução da realidade portuguesa ao longo da época contemporânea, dois outros

Cfr. P. Guimarães, 1989, p. 5 - prefácio de Maria Filomena Mónica. 
factores contribuem para garantir sentido a esta tentativa de síntese. Por um lado, a actual desactivação do essencial da indústria mineira nacional; por outro, o atraso com que, entre nós, as ciências sociais dedicaram atenção a temáticas que, noutros países, têm sido alvo de inúmeras iniciativas de análise e intervenção.

A história e a geografia humana, a antropologia e a sociologia - ou "tecnologias interdisciplinares" como a arqueologia industrial e a museologia - só a partir de meados/finais dos anos oitenta começaram a estruturar projectos de investigação e salvaguarda acerca deste mesmo objecto. Realce, quer para as atitudes pioneiras de Jorge Custódio, Paulo Guimarães e Helena Alves, quer, uma década e meia mais tarde, para a função dinamizadora assumida pelos Instituto Geológico e Mineiro, Instituto Superior Técnico e Faculdade de Engenharia da Universidade do Porto. Seguiram-se outros estudos, concretizados ou em vias de realização sobretudo no âmbito de seminários de licenciatura, cursos de mestrado e provas de doutoramento 2 .

Contrastando com o sucedido nas áreas das engenharias e da geologia, do direito e da medicina, da economia e da gestão, um tal atraso dever-se-ia às proibições e aos bloqueios resultantes da natureza ditatorial (tendencialmente totalitária) do Estado Novo. Ao relativo subinvestimento, às dificuldades de auto-organização e de rentabilização dos meios disponibilizados existentes mesmo depois da Revolução iniciada a 25 de Abril de 1974 (da instauração de um regime democrático).

Nos últimos trinta anos, a actividade extractiva tendeu a resumir-se, em Portugal, cada vez mais à exploração de pedreiras, rochas ornamentais, águas com ou sem propriedades medicinais, outros minerais não-metálicos. Fechou-se, pois (definitivamente?), um ciclo produtivo iniciado após 1850, no período da Regeneração. Enquanto vector do processo de integração na economiamundo capitalista, o sector mineiro contribuiu para o configurar do nosso país como espaço semi-periférico - ou, talvez melhor, como "periferia próxima" das maiores potências industriais europeias.

Cfr., essencialmente, H. Alves, 1997; H. Alves, 2000; Arqueologia e museologia [...], 2000; Congresso Internacional [...], 2002; J. Custódio, 1984; J. Custódio, 1993; D. Freire, 2001 ; J.C. Garcia, 1996; F. Gaspar, 1992; P. Guimarães, 1989; P. Guimarães, 1995; P. Guimarães, 1999/2000; P. Guimarães, 2001; M.O.P. Lage, 2000; J.M.A. Mendes, 1998; J.P.A. Nunes, 1999; J.P.A. Nunes, 2000a; J.P.A. Nunes, 2000b; M. Rego, 1996-2002; I.V. Rocha, 1997; J.A.E.S. Silva, 1996; A. Vilar, 1998; F. Vitorino, 2000; F. Vitorino, 2002. 
Mau grado o facto de, entre nós, se localizarem, por exemplo, significativas reservas de pirites, volframite e cassiterite - lembram-se os casos de NevesCorvo, Aljustrel e Panasqueira -, encontra-se hoje encerrada a generalidade das concessões. Trata-se do resultado de um amplo conjunto de factores: pequena dimensão, natureza dispersa ou esgotamento de muitos dos jazigos e depósitos; quase-ausência de transformação e incorporação industrial dos concentrados; interesses e necessidades dos "mercados internacionais" (das grandes empresas e das nações dominantes); políticas económicas do Estado e opções de investimento do empresariado português.

Adquirem, deste modo, particular actualidade e urgência questões como a poluição derivada de cortas, galerias e escombreiras abandonadas; as sequelas deixadas pelos acidentes e doenças profissionais. A situação das localidades fortemente marcadas pela presença de empresas concessionárias que suspenderam ou encerraram a laboração; o balanço do papel desempenhado pelo sector extractivo no desenvolvimento regional e nacional. O caracterizar das comunidades mineiras e do universo extractivo em geral; a preservação da sua memória e a fruição crítica (musealizando e/ou reutilizando) dos correspondentes testemunhos - documentação material, gráfica, audio-visual, escrita e oral ${ }^{3}$.

Ensaia-se, assim, no presente texto, uma apresentação necessariamente sumária de informação e de propostas interpretativas disponíveis sobre o comportamento da indústria extractiva localizada em Portugal Continental no período de tempo que decorreu entre o derrube definitivo do Antigo Regime, o suceder de vários regimes sociais globais e a entrada numa fase de "crescimento económico moderno". Simbolizável pelo arranque do I Plano de Fomento (19531958) da ditadura liderada por António de Oliveira Salazar, acarretou um intensificar do ritmo de emigração (sobretudo com destino à Europa Ocidental) e de transfereência de população para as cidades do litoral; um elevar dos níveis de industrialização e terciarização, consumo de massas e complexificação do aparelho de Estado ${ }^{4}$.

Cfr., nomeadamente, L. Aires-Barros, 1983; C. Arenas Posadas, 1999; Arqueologia e museologia [...], 2000; R. Bosson, 1977; Congresso Internacional [...], 2002; L.R. Costa, 2000; R. Garcia, 1998; J. Mc Divitt, 1962; Mineral potential of Portugal, 1998; J. Nash, 1993; J.M.S. Oliveira, 1997; D. Reid, 1985.

‘ Cfr., entre outros, J.M.A. Mendes, 1999; F. Rosas, 2000; A.J. Telo, 2000b; N. Valério, 1995. 


\section{Legislação, instituições e políticas ${ }^{5}$}

Não se terão verificado no nosso país - ao contrário do sucedido em outros Estados - fenómenos regulares de "contestação popular", quer da separação entre propriedade do solo e do subsolo, quer da presença de empresas e quadros superiores ou chefias intermédias oriundos de outras regiões ou nacionalidades. As únicas exepções a uma tal 'norma' resultariam dos três períodos de boom do volfrâmio e do estanho, coincidentes com a Primeira Grande Guerra (1914-1918), a Segunda Guerra Mundial (1939-1945) e a Guerra da Coreia (1950-1953).

Com reflexos na confrontação político-ideológica, na legislação e na praxis administrativa, as principais questões motivadas pelo sector extractivo derivaram da necessidade de limitar os prejuízos resultantes da ocupação e degradação de terrenos ou paisagens, da destruição de culturas ou floresta, do desvio e poluição de cursos de água, da contaminação de lençóis freáticos e das chuvas ácidas. Procurava-se anular ou controlar os "efeitos secundários do arranque, separação e concentração", bem como indemnizar os afectados. Assumiu-se, no entanto, por norma, que a mineração teria prevalência relativamente às outras actividades ou interesses.

Debateu-se, ainda, quais seriam as modalidades e os níveis adequados de tributação. De que modo se contribuiria para o financiamento das despesas públicas, promoveria a actualização tecnológica e organizativa das sociedades mineiras, apoiaria o desenvolvimento das indústrias metalúrgico-siderúrgica e química em Portugal Continental. Em sentido inverso, como garantir os lucros das empresas e a sua competitividade nos mercados externos, como compensar as insuficiências nacionais em termos de meios de transporte, fornecimento de energia, importação de maquinaria, etc.

Argumentou-se, também, sobre as responsabilidades do aparelho de Estado e dos particulares nos âmbitos do inventário sistemático dos recursos geológicos e da qualificação da força de trabalho. Da utilização "benéfica ou abusiva" de mão-de-obra estrangeira, do cumprimento das regras de higiene e segurança

Cfr., nomeadamente, H. Alves, 2000; P. Guimarães, 1995; P. Guimarães, 1999/2000; P. Guimarães, 2001; M.O.P. Lage, 2000; T. Leal, 1942; C. Lourenço, 1997a; C. Lourenço, 1997b; J.L.B. Ramos, 1994; M. Rego, 1996-2002; I.V. Rocha, 1997; M. Rodrigues Junior, 1921; M.L. Rodrigues, 1999; F. Vitorino, 2000; F. Vitorino, 2002. 
laboral. Do controlo da "lavra ambiciosa" e da "exploração informal", da subexploração dos jazigos, da suspensão injustificada da actividade, da exportação de matérias-primas quase sem transformação e incorporação industrial.

Por motivações de ordem diversa - filantropia ou consciência de direitos, prevenção de movimentos grevistas ou revolucionários, enquadramento dos assalariados e aumento da produtividade, etc. - analisaram-se, finalmente, soluções de apoio ao "pessoal superior", funcionários, capatazes e mestres, operários das empresas mineiras. Encararam-se áreas como a habitação e os transportes, a alimentação e a saúde, os acidentes e as doenças profissionais, a educação e a prática religiosa, a cultura e o lazer, o desemprego e a invalidez.

Visando alterar uma situação de quase-monopólio, arbitrariedade e semidesactivação que, pelo menos desde o século XVIII, definiria o universo mineiro metropolitano, os Governos pós-Convenção de Évora Monte (27 de Maio de 1834) ensaiaram a aplicação de "medidas liberalizadoras", encaradas como indispensáveis ao seu crescimento. Tratou-se de um normativo que diminuia as responsabilidades financeiras e o nível de intervenção directa do Estado, que abria o sector à iniciativa privada.

Foi, assim, abandonado o conturbado projecto de desenvolvimento das actividades extractiva e metalúrgica protagonizado, entre Maio de 1801 e Novembro de 1836, pela Intendência Geral de Minas e Metais do Reino. Criada, a 18 de Maio de 1801, por iniciativa de Rodrigo de Sousa Coutinho (Presidente do Real Erário), inicialmente dirigida por Bonifácio de Andrade e Silva e configurada através do Regimento das Minas e Metais do Reino (Alvará de 30 de Janeiro de 1802), resultou de um esforço de adaptação das concepções mercantilistas à concorrência e aos desafios introduzidos pelo processo de estruturação e expansão do capitalismo (na época, sobretudo, a partir da "revolução industrial" britânica).

Antes, mesmo, da consolidação definitiva do regime liberal entre nós, por intermédio de Decreto de 13 de Agosto de 1832, já José Xavier Mouzinho da Silveira atribuia a posse dos bens do subsolo - e os correspondentes direitos de exploração - aos mesmos cidadãos, nacionais ou estrangeiros, que tivessem obtido títulos de propriedade sobre os terrenos à superfície. À semelhança do ocorrido em outros âmbitos, pretendia o Ministro e Secretário de Estado dos Negócios da Fazenda implantar o modelo inglês de relacionamento entre Estado e "sociedade civil". 
Tratou-se de uma solução provisória, sem aplicação prática. A partir do fim da guerra civil entre liberais e absolutistas, toda a produção jurídica nacional relativa ao sector extractivo passou a inspirar-se na "Lei de minas" francesa de 21 de Abril de 1810 e no direito alemão. Os recursos do subsolo eram encarados como propriedade de "a Nação", a qual, por intermédio do Estado, podia concessionar a sua exploração a agentes económicos tidos como viáveis (dispondo dos meios financeiros, tecnológicos e humanos necessários ao exercício continuado da "exigente actividade mineira"). Mantinha, no entanto, os direitos de fiscalização, cobrança de impostos, intermediação nos conflitos de interesses entre concessionários, trabalhadores, proprietários de terrenos, comunidades afectadas pela poluição resultante da indústria extractiva.

Por intermédio de Portaria de 24 de Outubro de 1836 e de Circular com a mesma data, ambas da responsabilidade de Manuel da Silva Passos, era criada uma comissão que deveria apresentar "com urgência" um projecto de "Lei de minas". Uma vez auscultados os Administradores Gerais dos Distritos, o novo quadro jurídico regularia aquela "fonte de riqueza e prosperidade pública, propondo ao mesmo tempo os meios conducentes para se tirar a maior vantagem das existentes, a fim de se levarem prontamente a efeito e se dar a este interessante ramo todo o desenvolvimento de que for susceptível em proveito do Estado"'.

Com o Decreto de 25 de Novembro de 1836, empresas privadas de capitais nacionais ou estrangeiros passaram a poder dedicar-se, em Portugal Metropolitano, à actividade extractiva. Através das estruturas nacionais, distritais e concelhias da Secretaria de Estado dos Negócios do Reino, foi estabelecido um procedimento administrativo que ia desde o registo do manifesto de descoberta de um jazigo ou depósito à publicação do alvará de concessão (ainda de natureza temporária). Exigiu-se a contratação de um Director Técnico com habilitações reconhecidas; definiu-se um imposto proporcional de 5\% sobre o "rendimento líquido das minas", o qual era calculado subtraindo ao valor dos minérios (em bruto ou "preparados") as despesas feitas tendo por objectivo a sua produção.

Obrigou-se à aprovação prévia de "planos de lavra" (tentanto evitar exploração "ambiciosa" ou de "de rapina"), à apresentação periódica de relatórios das actividades concretizadas e de dados estatísticos. Fixaram-se, 
quer modalidades de atenuação dos efeitos de destruição e poluição, quer mecanismos de compensação devidos aos proprietários dos terrenos (bem como a outras entidades afectadas) nas fases de pesquisa e extracção. Explicitaram-se os prazos a partir dos quais, por ausência de trabalhos ou em resultado de outras infracções, as minas poderiam ser declaradas abandonadas. Foram isentados de direitos de importação durante 20 anos as máquinas e instrumentos estrangeiros necessários ao funcionamento das concessões. Previu-se a criação de uma "Escola de Minas" e de "escolas de mineiros".

A Lei de 25 de Julho de 1850 veio sistematizar os princípios e mecanismos definidos em 1836. No que concerne aos ajustamentos nucleares, referem-se a introdução da figura jurídica da "concessão por tempo ilimitado"; existência de um imposto fixo anual dependente da superfície do terreno demarcado (80 réis por cada 10 mil braçadas quadradas) e de um imposto proporcional à quantidade de minério extraída (5\% do "produto líquido da mina"); isenção fiscal nos 2 primeiros anos após o atribuir da concessão; não pagamento de taxas alfandegárias por parte de concentrados mineiros exportados. Institui-se, também, na dependência do Ministério dos Negócios do Reino, a Comissão Consultiva de Minas, antecessora, em simultâneo, dos futuros Direcção-Geral de Minas e Serviços Geológicos e Conselho Superior de Geologia e Minas".

Por intermédio de três Decretos de 30 de Agosto de 1852, foi criado o Ministério das Obras Públicas, Comércio e Indústria (MOPCI). Integrava, para além de outras repartições e organismos, a Direcção-Geral das Obras Públicas e Minas e o Conselho Geral de Obras Públicas e Minas (este último com funções consultivas). O quadro de funcionários da recém-fundada estrutura governamental deveria ser preenchido, tanto quanto possível, "com empregados do Ministério do Reino ou de qualquer outra repartição do Estado"10.

Da autoria de Carlos Ribeiro - Chefe da Repartição de Minas, Pedreiras e Trabalhos Geológicos da Direcção-Geral das Obras Públicas e Minas - e de F.A. Pereira da Costa (docente de mineralogia e geologia na Escola Politécnica de Lisboa), o Decreto de 31 de Dezembro de 1852 e o Decreto Regulamentar de 9 de Dezembro de 1853 respeitaram os pressupostos que informavam a legislação imediatamente anterior. Mantiveram-se em vigor até depois do deflagrar da Primeira Grande Guerra".

Cfr. $C O L P, 2^{\circ}$ Semestre de 1836, p. $163-165$.
Cfr. $C O L P, 2^{\circ}$ Semestre de 1850, p. 484-489.
${ }^{10}$ Cfr. $C O L P, 2^{\circ}$ Semestre de 1852, p. 383-385.
${ }^{\prime C}$ Cfr. $C O L P, 2^{\circ}$ Semestre de 1852, p. 909-918; COLP, $2^{\circ}$ Semestre de 1853, p. 737-751. 
No âmbito do MOPCI, a Repartição de Minas, Pedreiras e Trabalhos Geológicos e o Conselho Geral de Obras Públicas e Minas passaram a ser os organismos responsáveis pelas tarefas político-administrativas relativas às indústrias extractiva e de transformação de minérios. A intervenção directa junto das empresas e das comunidades mineiras caberia aos Governadores Civis e Administradores dos Concelhos, Engenheiros de Minas de Distrito e, em situações de emergência, Engenheiros Inspectores ou Comissões de Inspecção propositadamente nomeados para o efeito.

Apesar da lógica de continuidade no que concerne às opções assumidas pelo Decreto de 25 de Novembro de 1836 e pela Lei de 25 de Julho de 1850, o relatório que antecede o Decreto de 31 de Dezembro chama a atenção para duas das múltiplas insuficiências que limitariam, tanto o desenvolvimento da indústria extractiva, como a capacidade de coordenação por parte do aparelho de Estado: o desconhecimento dos recursos geológicos e a escassez de técnicos com formação superior em ramos do saber como a geologia, as engenharias de minas, química e mecânica.

Partindo do reconhecimento da dimensão entretanto atingida e das exigências particulares do sector extractivo, através de dois Decretos de 5 de Outubro de 1859, chegou a ser determinada a extinção do Conselho de Obras Públicas e Minas e a criação do Conselho de Obras Públicas e do Conselho de Minas. Em 1864 regressou-se ao modelo de uma única estrutura consultiva, prevendo-se, no entanto, de acordo com as necessidades, o funcionamento da mesma em plenário ou em secções especializadas ${ }^{12}$.

Tendo em conta o aumento da actividade mineira e a proliferação de situações de "abuso e especulação", por intermédio de Decretos de 15 de Abril de 1862 e de 13 de Agosto de 1862, visou-se, tanto aperfeiçoar os mecanismos de indemnização dos proprietários de terrenos prejudicados - os quais passariam a receber uma percentagem do valor obtido pela venda dos minérios ou concentrados produzidos -, como introduzir novas regras para a delimitação das "áreas normais" das concessões ${ }^{13}$.

O Corpo de Engenharia Civil e o Conselho Geral de Obras Públicas e Minas, estruturas do MOPCI, foram autonomizados, reorganizados e ampliados, vendo, ainda, as suas competências modificadas pelos Decreto de 3 de Outubro de 1864 e Portaria de 6 de Março de $1868^{14}$. De acordo com João Crisóstomo de

${ }^{12}$ Cfr. COLP, $2^{\circ}$ Semestre de 1859, p. 647-662.

${ }^{13}$ Cfr. $C O L P, 1^{\circ}$ Semestre de 1862, p.86-87; COLP, $2^{\circ}$ Semestre de 1862, p. 251/252.

${ }^{14}$ Cfr. COLP, $2^{\circ}$ Semestre de 1864, p. 773-786; COLP, $1^{\circ}$ Semestre de 1868, p. 73. 
Abreu e Sousa, responsável pela pasta, ter-se-ia tratado de um reforma indispensável tendo em conta o ritmo de modernização que então se verificava no país e a necessidade de o Estado, por um lado concretizar os seus próprios projectos, por outro fiscalizar a actividade dos particulares.

Subordinados ao Director-Geral das Obras Públicas e Minas, o Corpo de Engenharia Civil e o Corpo Auxiliar de Condutores ficariam organizados, entre

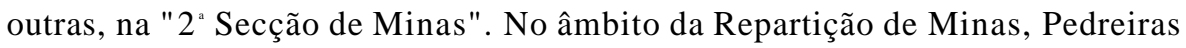
e Trabalhos Geológicos, passariam a ser responsáveis pelos "estudos, trabalhos técnicos e a administração, fiscalização e polícia concernente a: $1^{\circ}$ Pesquisa, exploração e lavra das minas, pedreiras, turfeiras e mais jazigos minerais; $2^{\circ}$ Fornos, forjas e oficinas dependentes da lavra dos jazigos minerais; $3^{\circ}$ Estatística mineralógica do País; 4 Carta geológica, pesquisa, exploração e análise das águas; $5^{\circ}$ Estabelecimento e laboração de máquinas e oficinas em relação à segurança, cómodo e salubridade pública"'s.

Argumentando com a necessidade de reduzir as despesas públicas mas visando, na prática, voltar a assegurar aos membros do Corpo de Engenharia Militar (criado a 12 de Fevereiro de 1812) o monopólio das "funções técnicas" do aparelho de Estado, por Decreto de 30 de Outubro de 1868 foram extintos o Corpo de Engenharia Civil e os Corpos Auxiliares de Condutores, Arquitectos e Desenhadores. Através de Decreto de 30 de Dezembro de 1968, o Governo liderado pelo Marquês de Sá da Bandeira determinou, ainda, a substituição do Conselho Geral de Obras Públicas e Minas pela Junta Consultiva de Obras Públicas e Minas ${ }^{16}$.

Reconhecendo a necessidade e as vantagens sociais de um aprofundar do processo de especialização e complexificação do aparelho de Estado, com o Decreto de 19 de Dezembro de 1869, o Governo procedeu a uma nova reorganização dos serviços de Obras Públicas e Minas do MOPCI. Voltaram a existir as secções autónomas de Obras Públicas e de Minas; reafirmou-se a incompatibilidade entre o estatuto de engenheiro ou condutor do Estado em "serviço activo" e o desempenho de actividades profissionais em empresas privadas; foram criadas três Direcções de Serviços de Minas (com sede em Lisboa, Porto e Coimbra) ${ }^{17}$.

${ }^{15}$ Cfr. $C O L P, 2^{\circ}$ Semestre de 1864, p. $775 / 776$.

${ }^{16}$ Cfr. COLP, $2^{\circ}$ Semestre de 1868, p. 372-375; COLP, $2^{\circ}$ Semestre de 1868, p. 603.

${ }^{17}$ Cfr. COLP, 2 ${ }^{\circ}$ Semestre de 1869, p. 830-833. 
Pela primeira vez desde a instauração no nosso país de um regime liberal conservador, a Portaria de 31 de Agosto de 1875 refere-se especificamente à problemática dos acidentes de trabalho ocorridos em minas e pedreiras. Visarse-ia criar condições para uma rápida intervenção, tanto das estruturas administrativas de âmbito distrital ou concelhio, como dos "agentes técnicos do Estado" ou, na falta destes, dos engenheiros ou condutores de minas com residência mais próxima dos locais dos sinistros; organizar um acervo estatístico que facilitasse, quer o produzir de documentos legais eficazes, quer uma redução do "elevado número de desastres".

Dirigida por António Cardoso Avelino (Chefe da Repartição de Minas, Pedreiras e Trabalhos Geológicosdo MOPCI) a todos os Governadores Civis do Continente, a Portaria em causa exige destes - por si próprios, com a colaboração dos Administradores dos Concelhos e dos Regedores das Freguesias na sua dependência - a recolha e transmissão imediatas de informações pertinentes (dia, hora e local do acidente, causas prováveis, número de mortos, número e situação dos feridos, extensão dos estragos materiais, instituições ou modalidades de solidariedade social). Previa-se, igualmente, a eventual requisição de apoio especializado por parte de engenheiros ou de condutores de minas com ou sem vínculo ao Estado ${ }^{18}$.

Ao pretender aperfeiçoar e uniformizar os métodos de trabalho dos engenheiros e condutores de minas ao serviço da administração pública (incluindo a recolha de dados estatísticos para tratamento e divulgação periódica da informação relevante), as Portarias de 18 de Dezembro de 1882 e de 8 de Novembro de 1883 são um exemplo significativo de como, mesmo num país semi-periférico, foi possível atingir níveis elevados de "espírito de corpo" e de "brio profissional". Revelam, também, a importância dos "vectores de modernização" - mesmo se minoritários, presentes no aparelho de Estado e na "sociedade civil" - no evoluir de cada espaço nacional ${ }^{19}$.

A 18 de Novembro de 1885, um Governo cuja liderança era, uma vez mais, assegurada pela personalidade incontornável de Fontes Pereira de Melo, procurou voltar a criar no MOPCI um "Corpo Civil de Engenheiros de Obras Públicas, Minas e Florestas", assim como os respectivos "Corpos Auxiliares"20.

${ }^{18} \mathrm{Cfr}$. COLP, ${ }^{\circ}$ Semestre de 1875, p. 210.

${ }^{19}$ Cfr., COLP, $2^{\circ}$ Semestre de 1882, p. 577; COLP, $2^{\circ}$ Semestre de 1883, p. 335-337.

${ }^{20}$ Cfr. Decreto de 18 de Novembro de 1885, COLP, $2^{\circ}$ Semestre de 1885, p. 645-652. 
O Decreto em causa acabou, no entanto, por não ser regulamentado, ficando, assim, no plano das decisões (ou, melhor, das intenções) não concretizadas.

Foi necessário esperar pelo ano seguinte e por um novo Executivo para que, através de Decreto de 30 de Dezembro de 1886, tivessem sido reestabelecidos no MOPCI o Corpo de Engenheiros de Obras Públicas e os Corpos Auxiliares de Condutores, Arquitectos e Desenhadores ${ }^{21}$. Encerrava-se, desta forma, um conflito entre "engenheiros militares" e "engenheiros civis" que se prolongava, pelo menos, desde o início dos anos cinquenta (tendo atingido níveis máximos de crispação após a publicação dos já referidos documentos legais de 1864 e 1868).

Optou-se, entretanto, por não integrar na referida orgânica os engenheiros de minas e os engenheiros florestais. Argumentou-se para o efeito que o Estado não explorava minas, pedreiras ou nascentes de águas medicinais, sendo, apenas, responsável por estudos geológicos, pela coordenação e acompanhamento da actividade dos concessionários privados. Apenas teria a seu cargo um número mínimo de áreas de mata, para além de a formação académica e as responsabilidades profissionais dos técnicos dos serviços florestais serem "inferiores aos dos seus congéneres de outras especialidades".

Através de um Decreto datado de 30 de Setembro de 1892, foi revista a "Lei de minas" vigente desde 31 de Dezembro de 1852. Mais do que alterações estruturais, procurou-se simplificar os procedimentos administrativos e clarificar as situações em que poderiam ocorrer infracções - em que se tornava necessária a intervenção fiscalizadora da Repartição de Minas ou a aplicação de penalizações por parte do MOPCI, ouvida a Junta Consultiva das Obras Públicas e Minas. Continuam, no entanto, ausentes determinações acerca das responsabilidades das sociedades mineiras em termos das condições de trabalho e de vida dos seus funcionários e operários ${ }^{22}$.

Publicado, ainda, a 30 de Setembro de 1892, um segundo Decreto abordou, de forma exclusiva, a problemática da tributação mineira. Concretizando projectos de reforma que já haviam sido apresentados "às Câmaras", sem sucesso, em 1878, 1881, 1883 e 1884, os empresários ou sociedades passaram a ter de entregar ao Estado, em cada ano, 300 ou 500 réis por cada hectare de superfície concedida (imposto fixo); $2 \%$ sobre o valor "à boca da mina" da produção realizada (imposto proporcional).

${ }^{21}$ Cfr. COLP, $2^{\circ}$ Semestre de 1886, p. 428-440.

Cfr. COLP, 2 ${ }^{\circ}$ Semestre de 1892, p. 762-768. 
Visou-se, deste modo, combater a especulação com os terrenos potencialmente ricos em jazigos ou depósitos, penalizar os concessionários que mantinham as suas minas inactivas, evitar a fraude fiscal resultante da sobrevalorização dos custos de laboração sem beliscar a "inviolável área de privacidade das empresas", incentivar a modernização tecnológica das explorações ${ }^{23}$. Continuava, no entanto, por solucionar o problema da enorme diferença entre a cotação virtual dos minérios em Portugal e o preço real pelo qual os mesmos eram vendidos nos países para onde - na sua quase totalidade e com a excepção do carvão ou do ferro - eram exportados.

Por intermédio de uma modalidade de isenção do imposto proporcional de minas e da possibilidade de não pagamento, durante 20 anos, do imposto industrial, procurou-se apoiar a transformação de minérios nacionais, ou seja, a criação e desenvolvimento em Portugal das indústrias química, metalúrgica e siderúrgica. Em sentido inverso, anulando em parte os efeitos daquela política de fomento, a exportação de concentrados continuava a não estar sujeita qualquer tributação.

À semelhança do que já acontecera com a Portaria de 31 de Agosto de 1875, referente, apenas, ao universo mineiro, também a Portaria de 7 de Agosto de 1897, englobando, agora, todas as actividades industriais, procurou aumentar a capacidade de o Estado recolher, em tempo útil e de forma exaustiva, informações acerca dos acidentes de trabalho ocorridos em Portugal metropolitano. Responsáveis por essa função seriam as próprias empresas, os inspectores da Repartição da Indústria e da Repartição de Minas, as "autoridades administrativas" (Governadores Civis, Administradores dos Concelhos, Regedores das Freguesias).

Tratou-se, assim, do reflexo de uma crescente pressão social, de uma ampliada consciência técnica e político-administrativa - pelo menos no que diz respeito aos diversos ramos da actividade transformadora - acerca da excessiva dimensão, dos elevados custos humanos e materiais que o fenómeno da sinistralidade laboral então assumia no nosso país. O documento legal em causa acaba, ainda, por revelar uma outra faceta significativa: a incapacidade ou a ausência de vontade política para, quer penalizar os empregadores e técnicos considerados culpados, quer assegurar apoios e compensações (temporários ou permanentes) aos trabalhadores afectados ${ }^{24}$. 
Dois conjuntos de Decretos publicados a 28 de Dezembro de 1899 e a 24 de Outubro de 1901 ampliaram, profissionalizaram e complexificaram as estruturas do MOPCI (Direcção-Geral de Obras Públicas e Minas incluída). Seguindo, entre outros, o exemplo francês, retomavam as concepções modernizadoras que estiveram na origem de legislação anterior, as quais haviam, por sua vez, sido contrariadas por documentos legais da responsabilidade de Governos defensores de modelos de economia, sociedade e aparelho de Estado mais conservadores ${ }^{25}$.

Enunciando os objectivos de corresponder às crescentes exigências de especialização técnica e de eficácia por parte do Estado e da sociedade civil, de consolidação de um conjunto de funcionários qualificados, com espírito de corpo e noção do serviço público, passou a ser o seguinte o organigrama da referida Direcção-Geral. Os Serviços de Engenharia Civil integrariam um Corpo de Engenharia com as Secções de Obras Públicas e de Minas, sendo os seus membros recrutados, preferencialmente, de entre os melhores alunos, com nacionalidade portuguesa, das Escolas Superiores de Engenharia de Lisboa e Porto ou entre os Tenentes da Arma de Engenharia (em regime de comissão).

Foi imposta uma estrutura rígida (quase militarizada) em termos de ingresso, desempenho profissional em regime de exclusividade, hierarquias, formação complementar, avaliação da actividade, progressão na carreira e reforma - sendo colocados obstáculos à saída (temporária ou definitiva) para empresas privadas. Regras semelhantes aplicaram-se, ainda, aos Corpos Auxiliares de Condutores, Arquitectos e Desenhadores.

Os funcionários em causa seriam integrados nos quadros das diversas repartições, entre as quais a Repartição de Minas, as duas Circunscrições Mineiras (sediadas em Lisboa e no Porto) e a Comissão do Serviço Geológico. Os quadros superiores fariam parte, por direito próprio, do Conselho Superior de Obras Públicas e Minas, subdividido em quatro Secções, uma das quais, a terceira, adoptaria a designação de "Secção de Minas, Pedreiras, Águas MineroMedicinais e Serviços Geológicos" ou Conselho Técnico de Minas.

Anos depois do derube da Monarquia e no contexto da Primeira Grande Guerra, aprovando a Lei $n^{\circ} 494$, de 16 de Março de 1916, o Congresso da República determinou a criação do Ministério do Trabalho e Previdência Social.

${ }^{25}$ Cfr. Decretos de 28 de Dezembro de 1899, COLP, $2^{\circ}$ Semestre, p. 899-907, 909, 915-924, 952/953; Decretos de 24 de Outubro de 1901, COLP, $2^{\circ}$ Semestre de 1901, p. 837-844, 844-856 e 856-860. 
Visou-se, inicialmente, a satisfação parcial das reivindicações sócio-laborais dos exíguos mas activos núcleos de operariado urbano, o desarticular das tendências "pacifistas e revolucionárias" assumidas pelos sindicatos e pelo movimento anarquista.

Este novo segmento da estrutura governamental acabou por atingir uma dimensão atípica, absorvendo, também, muitas das entidades públicas responsáveis pela gestão e o fomento das infraestruturas de transportes e comunicações, pela tutela das próprias actividades económicas privadas. Dois dos departamentos envolvidos na remodelação foram a Direcção Geral de Obras Públicas e Minas e a Direcção Geral da Indústria ${ }^{26}$.

Por intermédio da Lei $n^{\circ}$ 677, de 13 de Abril de 1917, concretizou-se um esforço de actualização parcial e de codificação dos princípios jurídicos e das soluções administrativas - das opções político-ideológicas - que condicionavam as actividades extractivas realizadas em Portugal Continental. Mantiveram-se, no essencial, os equilíbrios de interesses já explicitados na legislação anterior, embora seja possível detectar um reforço parcial das preocupações de natureza técnica, social e ambiental ${ }^{27}$.

Entre os aspectos mais inovadores, destacam-se: a prerrogativa de que o Governo passou a dispôr de negar a aprovação de um Director Técnico no caso de o mesmo ser já responsável por um número excessivo de concessões; a exigência de que, em explorações de média e grande dimensão, o Director Técnico residisse na mina. A obrigação de evitar ou, pelo menos, diminuir até níveis aceitáveis o grau de poluição de nascentes e cursos de água; o dever de as empresas subvencionarem, quer "a construção de estradas, do Estado e dos corpos administrativos, vias férreas e vias de navegáveis que sejam utilizadas para os transportes dos produtos das minas", quer a criação de "estabelecimentos de assistência pública de que aproveitem todos os operários mineiros." (p. 171)

São, ainda, de referir o facto de qualquer concessionário poder "requerer uma demarcação única para as minas limítrofes ou vizinhas de que seja possuidor, e que, para os efeitos da presente Lei, corresponderá a uma só demarcação de couto mineiro" (p. 171). A definitiva autonomização, no seio da Direcção-Geral de Obras Públicas e Minas, da Repartição de Minas, das Circunscrições Mineiras do Sul e do Norte, do Corpo de Engenharia de Minas e do Corpo Auxiliar de Condutores, do Conselho Superior de Minas.

${ }^{26}$ Cfr. COLP, $1^{\circ}$ Semestre de 1916, p. 186.

${ }^{27}$ Cfr. $C O L P, I^{\circ}$ Semestre de 1917, p. 166-175. 
Talvez por ter sido elaborado durante o consulado sidonista, pela primeira vez desde a liberalização da actividade mineira em Portugal Continental, o Decreto $\mathrm{n}^{\circ}$ 4: 159 , de 26 de Abril de 1918 - regulamentado pelo Decreto $\mathrm{n}^{\circ} 4$ : 544 , de 1 de Julho de 1918 e parcialmente anulado pelo Decreto $n^{\circ}$ 8: 371 , de 25 de Agosto de 1922 -, abordou, de forma autónoma, a questão dos prejuízos causados à agricultura pela poluição derivada da industria extractiva. Estabelecendo, embora, uma linha de continuidade face à legislação anterior e sendo da iniciativa da Repartição de Minas, atribuiu prevalência aos interesses da "lavoura", procurando definir procedimentos administrativos e judiciais que garantissem, quer a rápida indemnização dos agricultores afectados, quer a imediata montagem pelos concessionários de mecanismos que resultassem no desaparecimento ou na atenuação dos agentes poluidores ${ }^{28}$.

Reconhendo a necessidade de o Estado investir mais na sensibilização dos agentes económicos para os benefícios de um efectivo cumprimento da legislação sobre higiene e segurança do trabalho, acidentes e doenças profissionais, pelo Decreto ${ }^{\circ}$ 4: 191, de 13 de Abril de 1918, o Governo sidonista criou, no âmbito da Direcção-Geral do Trabalho do Ministério do Trabalho, a Inspecção Sanitária do Trabalho. O seu corpo de funcionários resumir-se-ia a 2 médicos e procuraria intervir em três âmbitos essenciais: recolha e tratamento de dados estatísticos, investigação e cooperação internacional, demonstração das vantagens económico-sociais de uma "organização racional da produção" ${ }^{29}$.

Foi através do Decreto ${ }^{\circ}$ 4: 641, de 13 de Julho de 1918, que, ainda integradas no Ministério do Trabalho e Previdência Social, as estruturas do aparelho de Estado especializadas na tutela das actividades extractivas assumiram a configuração que depois se manteve, com alterações mínimas, até depois de 1953. A Direcção-Geral de Minas e Serviços Geológicos, subdividida na Repartição de Minas - integrando as Circunscrições Mineiras do Sul e do Norte sediadas, respectivamente, em Lisboa e no Porto -, na Inspecção de Águas, na Inspecção de Pedreiras, no Laboratório QuímicoMetalúrgico e nos Serviços Geológicos; o Conselho Superior de Geologia e Minas, com as Secções de Minas, Águas, Impostos de Minas e Águas, Serviços Geológicos; o Corpo de Engenheiros de Minas, o Corpo Auxiliar de Condutores de Obras Públicas e Minas.

${ }^{28}$ Cfr. COLP, $1^{\circ}$ Semestre de 1918, p. 347/348; COLP, $2^{\circ}$ Semestre de 1918, p. 31-33; COLP, $2^{\circ}$ Semestre de 1922, p. 241-243 e, ainda, F Vitorino, 2000; F. Vitorino, 2002.

${ }^{29}$ Cfr. COLP, $I^{\circ}$ Semestre de 1918, p. 391. 
Ampliaram-se e consolidaram-se, igualmente, os serviços em teoria (ao nível dos princípios proclamados e aplicáveis, na melhor das hipóteses, aos centros urbanos e industriais) responsáveis pela fiscalização das condições de higiene e segurança no trabalho, pelo atenuar das dificuldades resultantes de acidentes e doenças profissionais, pela melhoria do nível de vida das classes populares. A Direcção-Geral do Trabalho, Direcção-Geral de Previdência Social, Direcção-Geral de saúde (da qual fazia parte a Inspecção Sanitária do Trabalho), Direcção-Geral de Assistência Pública e Conselho Nacional de Assistência Pública $^{30}$.

No âmbito de um processo de reforma global da tributação, consignado na Lei ${ }^{\circ}$ 1: 368, de 21 de Setembro de 1922, o Executivo liderado por António Maria da Silva assegurou a extinção do imposto proporcional de minas e a sua substituição pelo imposto sobre o valor das transacções, também com uma taxa de $2 \%$ mas visando todos os "actos de comércio, transporte ou transformação industrial" de que fossem alvo em Portugal Continental os minérios extraídos entre nós. Procurava-se, assim, atenuar a situação de sistemático escamoteamento, para efeitos fiscais, do efectivo valor de marcado (nos países importadores) dos concentrados produzidos.

Esta solução foi, entretanto, abandonada, em 1929, por um Governo da Ditadura Militar no qual António de Oliveira Salazar ocupava a pasta das Finanças. Depois de uma solução transitória, assegurada através da publicação do Decreto ${ }^{\circ}$ 17: 029, de 25 de Junho de 1929 - aplicação do imposto de sêlo, com taxa de $2 \%$ sobre o valor "à boca da mina" do minério comercializado -, anova"Lei de minas" (Decreto ${ }^{\circ}$ 18:713, de 11 de Julho de 1930) reintroduziu o imposto proporcional de minas nos termos definidos pelo normativo de 30 Setembro de $1892^{31}$.

Logo que ultrapassadas as especificidades da Primeira Grande Guerra "União Sagrada" e coordenação de políticas, gestão centralizada de recursos escassos -, apesar dos elogios a valores "trabalhistas" (ou "socialistas"), a concentração de um amplo conjunto de organismos públicos no Ministério do Trabalho e Previdência Social teria acabado por se revelar uma solução "pouco eficaz". Aquela estrutura governamental era, assim, extinta pelo Decreto $\mathrm{n}^{\circ} 11$ : 267, de 25 de Novembro de $1925^{32}$.

${ }^{30}$ Cfr. $C O L P, 2^{\circ}$ Semestre de 1918, p. 229-244.

${ }^{31}$ Cfr., COLP, ${ }^{\circ}$ Semestre de 1922, p. 268-276; COLP, $1^{\circ}$ Semestre de 1929, p. 1217; COLP, $2^{\circ}$ Semestre de 1930, p. 275-292.

${ }^{32}$ Cfr. COLP, $2^{\circ}$ Semestre de 1924, p. 739-746. 
Face aos valores atingidos pelas importações de carvão e mau grado as insuficiências qualitativas dos jazigos nacionais, seguindo medidas de "proteccionismo moderado" já ensaiadas no "interregno sidonista" (Decreto $\mathrm{n}^{\circ} 4801$, de 11 de Setembro de 1918), a Ditadura Militar e o Estado Novo incentivaram a produção interna e o consumo daqueles minérios não-metálicos. Após a implementação do Decreto ${ }^{\circ}$ 11: 852, de 3 de Julho de 1926 (instituindo a Comissão de Aproveitamento dos Carvões Nacionais) e de várias outras medidas de apoio directo e indirecto, a criação do Instituto Português dos Combustíveis (Decreto-Lei ${ }^{\circ} 22: 788$, de 29 de Junho de 1933) garantiu uma actuação integrada em defesa de um subsector não-concorrencial em termos externos ${ }^{33}$.

Por intermédio do Decreto ${ }^{\circ}$ 12: 477, de 12 de Outubro de 1926, instituiu-se, no âmbito da Direcção-Geral de Saúde do Ministério do Interior, a Inspecção de Higiene do Trabalho e das Indústrias. Passaria a caber ao organismo em causa lidar directamente com as questões da higiene e segurança no trabalho, acidentes e doenças profissionais. Coordenaria, nesta área específica, a actividade de delegados de saúde, médicos, postos de saúde e hospitais, funcionários dos serviços responsáveis pela fiscalização técnica das actividades industriais. Representaria Portugal nas estruturas especializadas da Organização Internacional do Trabalho (OIT) $)^{34}$.

Através do Decreto n ${ }^{\circ}$ 16: 206, de 7 de Dezembro de 1928, o Governo da Ditadura Militar autorizou "as empresas mineiras ou quaisquer outras que explorem indústrias em lugares afastados das sedes dos concelhos a que pertencem, cuja população mineira ou industrial não seja inferior a 500 pessoas, a criar e manter, exclusivamente à sua custa, uma polícia privativa. § único. Quando a população referida não seja inferior aquele número nem superior a 1000, o quadro policial será composto de 1 sub-chefe de esquadra e de 8 guardas; sendo superior a este último número, será o quadro composto de 1 chefe, 3 sub-chefes e pelo menos 18 guardas, número que poderá ainda ser aumentado conforme as exigências do serviço, com autorização da Intendência Geral da Segurança Pública, ouvido o comandante da polícia distrital."

Invocando um precedente legal de 1878 e o correspondente "bom exemplo" da Mina de S. Domingos, respondia-se, assim, de forma positiva, a solicitações

Cfr. COLP, $2^{\circ}$ Semestre de 1918, p. 528; COLP, $2^{\circ}$ Semestre de 1926, p. 28-30; COLP, $1^{\circ}$ Semestre de 1933, p. 976-978.

${ }^{34}$ Cfr. $C O L P, 2^{\circ}$ Semestre de 1926, p. 696-702. 
nesse sentido apresentadas por diversas empresas. Tratou-se, com efeito, do reconhecimento, por um lado da insuficiência de efectivos da Guarda Nacional Republicana, por outro, da natureza particular das comunidades mineiras (das concentrações operárias em geral) no que concerne ao poder totalizante exercido pelas sociedades concessionárias (pelas grandes companhias industriais em geral). Derivou, ainda, dos mais elevados níveis de consciência de classe e conflitualidade social dos trabalhadores, dos inabituais índices de desenraizamento e "criminalidade"

A primeira intervenção codificadora do novo regime no sector extractivo foi simultaneamente precoce e estruturante, discutida e aprovada na fase da Ditadura Militar, enquanto António de Oliveira Salazar ocupava, 'apenas', o cargo de Ministro das Finanças. A nova "Lei de minas" simbolizou, no entanto, a permanência da generalidade das soluções jurídicas adoptadas e da praxis político-administrativa concretizada durante a Monarquia Constitucional e a Primeira República.

Contrariamente ao proclamado no preâmbulo e ao sucedido em outros âmbitos da vida nacional, ignoravam-se, no essencial, as aspirações "nacionalistas e regeneradoras" dos sectores industrialistas do regime. Mesmo tendo em conta as modificações parcelares (complementos ou substituições) introduzidas ao longo do tempo, o Decreto $\mathrm{n}^{\circ}$ 18: 713, de 11 de Julho de $1930^{36}$, acabou por vigorar durante seis décadas. Foi revogado, apenas, pelos Decreto-Lei $n^{\circ} 88 /$ 190, de 16 de Março e Decreto-Lei n 90/90, 16 de Março - no que concerne às implicações ambientais da actividade extractiva, pelos Decreto-Lei $n^{\circ}$ 196/88, de 31 de Maio e Decreto-Lei n ${ }^{\circ}$ 198-A/2001, de 6 de Julho ${ }^{37}$.

O Estado manteve o estatuto de proprietário dos depósitos e jazigos minerais úteis, cabendo ao Executivo, quer a respectiva concessão, "por tempo ilimitado", a entidades privadas nacionais ou estrangeiras, quer a fiscalização nos planos técnico-económico, social e ambiental. Em caso de incumprimento grave das normas estabelecidas ou das orientações dadas, o organismo oficial tutelante imporia o pagamento de multas, o confisco de minério, a suspensão da lavra ou, mesmo, a declaração de abandono. Às partes envolvidas assistia, para além

${ }^{35}$ Cfr. $C O L P, 2^{\circ}$ Semestre de 1928, p. 827.

${ }^{36}$ Cfr. COLP, $2^{\circ}$ Semestre de 1930, p. 275-292.

${ }^{37}$ Cfr. Diário da República (DR), I Série, $\mathbf{n}^{\circ}$ 63, 16 de Março de 1990, p. 1273-12286 e 1289-1304; $D R$, I Série, $n^{\circ} 126,31$ de Maio de 1988, p. 2332/2333; $D R$, I Série-A, $n^{\circ} 155,6$ de Julho de 2001, p. 4084(2)-4084(7). 
do mais, o direito de recurso aos tribunais. Situações de conflito militar generalizado justificavam o aplicar de regras excepcionais no que concerne à produção, comércio interno e exportação de minérios.

Procedeu-se ao aligeirar da tramitação burocrática, tornando legítima a realização de trabalhos de pesquisa após o simples acto de manifesto ou registo de descoberta nas secretarias das Câmaras Municipais. Evidenciou-se a prevalência da mineração sobre a agro-silvicultura e pastoricia: obrigatoriedade de autorização das actividades extractivas legais, método de cálculo das compensações, possibilidade de expropriação de terrenos.

Reafirmaram-se os deveres dos concessionários em termos de controlo dos níveis de poluição; face aos proprietários ou usufrutuários atingidos (pagamento de rendas fixas e proporcionais, bem como de indemnizações), perante os trabalhadores empregues (segurança e higiene no trabalho, habitação e ensino primário, saúde e assistência), no que concerne aos poderes municipais interessados (construir e reparar vias de comunicação).

Explicitaram-se melhor as obrigações já antes fixadas aos empresários mineiros relativamente ao "interesse colectivo". Efectiva exploração dos jazigos; concretizar de "lavra racional", de acordo com planos e orientação técnica aprovados. Manutenção da "ordem pública" e aplicar dos "princípios corporativos". Envio de informações estatísticas rigorosas e notificação imediata dos acidentes ocorridos; utilização adequada das guias de trânsito obrigatórias. Pagamento anual dos impostos fixo ( $2 \$ 50$ ou $5 \$ 00$ por hectare de superfície concedida) e proporcional ( $2 \%$ do valor do minério "preparado para o mercado"), acrescidos das taxas cobráveis pelas Câmaras Municipais e Juntas de Freguesia.

Se, por um lado, era garantida isenção do imposto proporcional aos carvões e minérios de ferro a aplicar na indústria siderúrgica que viesse a instalar-se em Portugal Continental, por outro as taxas de exportação de concentrados (matérias-primas escassamente transformadas) permaneciam nulas ou irrelevantes. Mau grado as indicações de atribuição de preferência a bens e serviços nacionais, continuavam a ser possíveis as autorizações de importação bonificada de tecnologia estrangeira, desde sempre hegemónica na actividade extractiva realizada entre nós até pela quase-inexistência de alternativa.

Uma tal ambivalência - esforço de conciliação de interesses opostos, resultado da crise internacional que se prolongou ao longo dos anos trinta, pragmatismo face aos "inevitáveis constrangimentos económicos"? - detecta- 
-se, também, no impor de Directores Técnicos portugueses versus a possibilidade, restringida embora, de contratação de assalariados ("pessoal dirigente", funcionários, chefias intermédias, operários) de outras nacionalidades. Na distância entre os preceitos legais e a realidade concreta, tanto das explorações mineiras, como da intervenção do aparelho de Estado. Na lógica casuística (parcelar e/ou descontínua) das iniciativas públicas dinamizadoras e reorganizadoras do sector face às dificuldades manifestadas pelos agentes privados.

Através dos Decreto ${ }^{\circ}$ 18: 768, de 18 de Agosto de 1930 e Decreto-Lei ${ }^{\circ}$ 26:974, de 2 de Setembro de $1936^{38}$, o Conselho Superior de Geologia e Minas, estrutura de consulta da DGMSG, passou a integrar, em acréscimo a quadros superiores de organismos da administração pública e de instituições de ensino superior, 3 representantes dos interesses económicos privados envolvidos: 1 pelos concessionários mineiros, 1 pelos concessionários de águas mineromedicinais, 1 pela Associação Central da Agricultura Portuguesa. Para além da concretização de valores corporativos e do atribuir de alguma capacidade de intervenção à "lavoura", realça-se a ausência, quer das Associações Industriais Portuguesa e Portuense, quer de associações profissionais e de classe (mais tarde, da Ordem dos Engenheiros e de Sindicatos Nacionais).

Correspondendo a opções políticas modernizadoras, obedecendo a uma lógica de racionalização e especialização administrativa, substituindo o Ministério do Comércio e Comunicações e o Ministério da Agricultura, o Decreto ${ }^{\circ}$ 21:454, de 7 de Julho de 1932, autonomizou o Ministério das Obras Públicas e Comunicações e concentrou todas as áreas económicas numa única pasta governamental: o Ministério do Comércio, Indústria e Agricultura. Em resultado da pressão exercida pelo lobby (conservador ou, mesmo, tradicionalista) da "lavoura", o Decreto-Lei n ${ }^{\circ} 22:$ 873, de 24 de Julho de 1933, voltou a consagrar a separação do Ministério da Agricultura e do Ministério do Comércio e Indústria ${ }^{39}$.

Reconhecendo vantagens na adaptação do articulado da "Lei de minas" à sobreinstabilidade dos mercados internacionais de concentrados, o Governo do Estado Novo deu cobertura formal à sistemática opção administrativa de autorizar que, em conjunturas de quebra da procura e diminuição dos preços, os concessionários suspendessem a lavra ou desactivassem as explorações ${ }^{40}$.

Cfr. $C O L P, 2^{\circ}$ Semestre de 1930, p. 398-400; COLP, $2^{a}$ Semestre de 1936, p. 246/247.

"Cfr. COLP, $2^{\circ}$ Semestre de 1932, p. 31/32; COLP, $2^{\circ}$ Semestre de 1933, p. 102.

${ }^{4}$ Cfr. Decreto $n^{\circ}$ 27: 540, de 26 de Fevereiro de 1937, COLP, $I^{\circ}$ Semestre de 1937, p. 99. 
Ensaiou, também, o aperfeiçoamento de mecanismos de controlo e repressão do volume crescente de transacções irregulares de minérios (comércio interno e exportação), baseadas na produção, separação e transporte clandestinos, no falsificar de guias de trânsito ${ }^{41}$.

Dada a escalada de "actividades paralelas", ocorrida sobretudo nos universos do tungsténio e do estanho, determinou-se, ainda, que o formulário-base dos alvarás mineiros integraria os seguintes alertas: "As operações de lavra serão efectuadas directamente pela concessionária (ou arrendatária), que se não limitará a comprar minério ou a dar trabalhos de empreitada. Nos casos em que possa ser aceite a justificação de assim se não proceder tornar-se-á obrigatória a residência do director técnico no local dos trabalhos mineiros" ${ }^{42}$.

Promulgada cerca de 13 anos após a "Revolução Nacional" de 28 de Maio de 1926 e meses antes do deflagrar da Segunda Guerra Mundial, a "Lei de fomento mineiro" (Decreto-Lei $\mathrm{n}^{\circ}$ 29: 725, de 28 de Junho de 1939) ${ }^{43}$ surge como documento fundador de uma anunciada alteração das características e funções do sector extractivo nacional. Invocando argumentos como a responsabilidade das correntes e políticas ruralistas na manutenção dos níveis de pobreza e dos fluxos emigratórios, no reproduzir do endividamento externo e de inúmeras fragilidades estratégicas, defende-se a necessidade e viabilidade de concretizar uma industrialização sustentável (apenas temporária e moderadamente proteccionista).

Tratar-se-ia, assim, de um esforço sistemático, coordenado pelo aparelho de Estado e participado por entidades privadas, de identificação dos recursos mineiros efectivamente disponíveis, de alteração do estatuto do país enquanto área de reserva ou fornecedor permanente de matérias-primas. Visava-se acelerar a formação de especialistas e garantir o acesso a tecnologias mais eficazes; negociar outras modalidades de apoio e o estreitamento das ligações aos sectores metalúrgico, siderúrgico e químico. Isentar de direitos de importação a maquinaria estrangeira indispensável; baixar, quer o nível das tarifas ferroviárias e rodoviárias, quer os montantes da contribuição industrial; aperfeiçoar o quadro legislativo, concentrar e cartelizar os agentes económicos, instituir um Grémio patronal.

${ }^{41}$ Cfr. Decreto-Lei ${ }^{\circ}$ 28: 852, de 13 de Julho de 1938, COLP, ${ }^{\circ}$ Semestre de 1938, p. 38/39; Decreto-Lei $n^{\circ}$ 29: 179, de 24 de Novembro de 1938, COLP, $2^{\circ}$ Semestre de 1938, p. 341/342; Decreto $^{\circ}$ 30: 072, de 20 de Novembro de 1939, COLP, $2^{\circ}$ Semestre de 1939, p. 393.

${ }^{42}$ Cfr. Portaria n ${ }^{\circ}$ 8: 804, de 20 de Setembro de 1937, COLP, ${ }^{\circ}$ Semestre de 1937, p. 278.

${ }^{43}$ Cfr. COLP, $I^{\circ}$ Semestre de 1939, p. 469-474. 
Excepção feita aos jazigos de carvão e de ferro - tidos como prioritários mas não-concorrenciais no plano europeu e mundial, de qualidade insuficiente mesmo para os defensores de uma lógica semi-autárcica -, a acção do Serviço de Fomento Mineiro (iniciada em meados de 1940) acabou, no entanto, por só contribuir de forma relevante para o efectivar de um projecto modernizador a partir de meados dos anos 50. Mau grado o acesso (tardio e limitado embora) à "ajuda Marshall", as dificuldades e oportunidades inerentes ao conflito militar e ao imediato pós-guerra, as limitações orçamentais e de pessoal qualificado, os obstáculos ao estabelecimento de parcerias com empresas estrangeiras de prospecção, o peso do lobby tradicionalista e das grandes sociedades mineiras de capitais internacionais, justificariam este mesmo insucesso relativo.

Aproveitando o ambiente mobilizador da Segunda Guerra Mundial, por intermédio do Decreto-Lei $\mathrm{n}^{\circ}$ 30: 692, de 27 de Agosto de $1940^{44}$, o Estado Novo assumiu, a título definitivo, o controlo unificado dos vários sectores de actividade a partir do Ministério da Economia. Na fase de transição que se seguiu ao conflito, também as alterações aos estatutos de sociedades concessionárias de minas em Portugal Continental passaram a depender de autorização prévia por parte do Ministro da Economia ${ }^{45}$. Apenas no ano de 1950 foi extinta a Sub-Secretaria de Estado das Corporações e Previdência Social, optando-se pela criação de um Ministério das Corporações e Previdência Social ${ }^{46}$.

\section{O sector mineiro ${ }^{47}$}

Entre 6 de Agosto de 1836 e 24 de Novembro de 1953, foram concessionadas em Portugal Continental 2883 minas, algumas centenas das quais integradas

${ }^{4}$ Cfr. $C O L P, 2^{\circ}$ Semestre de 1940, p. 200.

"4 Cfr. Decreto-Lei ${ }^{\circ}$ 36: 367, 23 de Junho de 1947, COLP, $2^{\circ}$ Semestre de 1947, p. 439.

46 Cfr. Decreto-Lei ${ }^{\circ}$ 37: 909, 1 de Agosto de 1950, COLP, ${ }^{\circ}$ Semestre de 1950, p. 85/86.

"Cfr., entre outros, L. Aires-Barros, 1983; A.F. Almeida, 1946; H. Alves, 1997; H. Alves, 2000; C. Andrade, 1962; Anuário Estatístico de Portugal [1930]/Anuário Estatístico [1940]; Boletim de Minas [1911-1939]; J.A.C.N. Cabral, 1886; E. Campos, 1913; F.S. Carneiro, 1956; F.S. Carneiro, 1959; F.S. Carneiro, 1961; F.S. Carneiro, 1971; A.M.G. Carvalho, 2000; M.C. Cerdeira, 1988; M.C. Cerdeira, 1998; X Congresso [...], 1951; I Congresso [...], 1938; A.M. Costa, 1931; L.R. Costa, 2000; J. Custódio, 1984; C. Fonseca, s.d.; F.V. Fonseca, 1964; F.V. Fonseca, 1964; D. Freire, 2001; R. Garcia, 1998; F. Gaspar, 1992; O.C. Gaspar, 1998; S. Gesta, 1978;S.Gesta, 1981; L.Guerreiro, 1940;L.Guerreiro, 1952;P.Guimarães, 2001; A.L.A. Inglês, 1928; M.V. Leal, 1945; M.A.B.C. Lima, 1960a; M.A.B.C. Lima, 1960b; M.A.B.C. Lima, 1961; A. Louçã, 2000; M.G. Matias, 1987;F.M. Mendes, 1993; J.M.A. Mendes, 1999; Minas concedidas [...], 1963; J.G.Monteiro, 1948; F.P. Neves, 1979; A.M. Nogueira, 1939; G. Nunes, 1995;J.P.A. 
nos 51 coutos mineiros delimitados a partir de 1920. Enquanto a primeira concessão, Braçal e Malhada (chumbo), se localizava no concelho de Sever do Vouga (distrito de Aveiro), a última mina do período observado, Viduais (volfrâmio), situava-se no concelho e distrito de Vila Real.

Mesmo não considerando as explorações clandestinas e os manifestos de minas caducados, as concessões provisorias e as licenças de exploração introduzidas - a título "excepcional e temporário" - de 1942 a $1952^{48}$, estar-se-ia, sobretudo, face a pequenas explorações, apenas rentáveis e activas durante as conjunturas particularmente favoráveis. Tratou-se, em perto de $50 \%$ dos casos, de minas de ou com minérios de estanho e volfrâmio, localizadas nos distritos de Coimbra e Castelo Branco, Aveiro, Viseu e Guarda, Porto e Vila Real, Viana do Castelo, Braga e Bragança.

$\mathrm{Na}$ generalidade dos subsectores, o comportamento de indicadores pertinentes como os registos mineiros efectuados, as concessões de novas minas, a suspensão da lavra ou as declarações de abandono, as oficinas de tratamento de minérios licenciadas (dentro ou fora de concessões), resultou sempre mais da evolução dos mercados internacionais do que das modestas ou pouco consequentes alterações das políticas mineiras - económico-sociais em geral nacionais. Refiram-se, quanto à Ditadura Militar e ao Estado Novo, a "Lei de Minas" (1930), a "Lei de Reconstituição Económica" (1935), a "Lei de Fomento Mineiro" (1939), a "Lei de Fomento e Reorganização Industrial" (1945).

Apesar de no nosso país terem sido detectadas e exploradas um grande número de substâncias minerais úteis, em termos de quantidades extraídas e de riqueza gerada apenas atingiram valores significativos os minérios de cobre, enxofre, carvão, estanho, volfrâmio, ferro, manganés e chumbo. Se, em alguns casos, as fases de crescimento - ou, mesmo, de euforia - coincidiram com situações de estabilidade a nível europeu e mundial (minas de cobre, enxofre, manganés e chumbo), noutros dependeram de conjunturas de corrida aos

Nunes, 1999; J.P.A. Nunes, 2000a; J.P.A. Nunes, 2000b; J.M.S. Oliveira, 1997; M.F. Patriarca, 1995; J.J.A. Pereira, 1984; M.H. Pereira, 1999; I. Pimentel, 2000; M. Rego, 1996-2002; Relatório dos Serviços [...], 1912; M.I. Rezola, 1999; I.V. Rocha, 1997; M. Rodrigues Junior, 1921;M.L. Rodrigues, 1999; F. Rosas, 1986; F. Rosas, 1990; F. Rosas, 2000; Rumores subterrâneos [...], 1929; V. Sá, 1991; J.A.E.S. Silva, 1996; L.C. Sola, 1934; A.J. Telo, 1991; A.J. Telo, 2000a; A.J. Telo, 2000b; A. Vilar, 1998; F. Vitorino, 2000; F. Vitorino, 2002.

${ }^{48}$ Cfr. Decreto-Lei ${ }^{\circ}$ 32: 104, de 25 de Junho de 1942, COLP, $I^{\circ}$ Semestre de 1942, p. 331/ 332 e Decreto-Lei ${ }^{\circ}$ 38: 670, de 7 de Março de 1952, COLP, $I^{\circ}$ Semestre de 1952, p. 337/338. 
armamentos ou de confronto militar generalizado (minas de volfrâmio e estanho), de proteccionismo nacionalista, economia de guerra, industrialização por substituição de importações (minas de carvão e ferro).

Encarando a década de trinta do século XX como amostra minimamente representativa ${ }^{49}$, verifica-se que o caracterizar da população activa mineira existente em Portugal Continental continua a ser dificultada por um conjunto de obstáculos mais ou menos generalizáveis aos cerca de 120 anos em apreço. Em primeiro lugar, as habituais discrepâncias entre as várias estatísticas oficiais disponíveis. A subdimensionação dos efectivos de "mineiros" contabilizados (operários ou camponeses-operários), das referências a incapacitados ou mortos devido a acidentes de trabalho e a doenças profissionais.

Um tal fenómeno resultaria do carácter 'invisível' da mão-de-obra empregue nas explorações clandestinas, da utilização frequente de trabalhadores nãodeclarados (à jorna ou à tarefa) como forma de evitar mesmo as limitadas obrigações laborais vigentes; do escamotear de uma parcela significativa da sinistralidade ocorrida, do escasso empenhamento social na atenuação preventiva e compensatória - de patologias como a silicose (em termos legais, político-administrativos, empresariais). Variável era, também, o número de dias por ano em que os mineiros e os outros assalariados em causa, no essencial com vínculo precário, trabalhavam e eram remunerados.

Para um total de 6802 milhares de habitantes recenceados em 1930, Portugal contaria com 2517 milhares de formalmente activos (37\%), $1276(50,7 \%)$ dos quais no sector primário, $690(27,4 \%)$ no sector terciário e 551 (21,9\%) no sector secundário - $468(18,6 \%)$ na indústria transformadora e apenas $9(0,4 \%)$ na indústria mineira. Quanto a 1940, o universo global aumentara para 7755 milhares, 2775 milhares de activos (35,8\%), 1461 (52,6\%) no sector primário. $645(23,2 \%)$ no sector terciário, $669(24,1 \%)$ no sector secundário - $566(20,4 \%)$ na indústria transformadora e $26(0,9 \%)$ na indústria extractiva. Salienta-se o limitado peso inicial e o (modesto embora) crescimento da actividade extractiva; o reforço da posição dominante da agricultura e a ultrapassagem do sector terciário pelo secundário.

A hegemonia dos operários no conjunto dos activos mineiros (de um mínimo de $89,7 \%$ em 1932 a um máximo de 94,5\% em 1939) indicia, quer baixos graus de automatização das explorações e de sofisticação organizativa das

“ Cfr. Anuário Estatístico de Portugal [1930] e Anuário Estatístico [1940]; Boletim de Minas [1931-1939]; A.B. Nunes, 1989; F. Rosas, 1986. 
empresas, quer uma oferta abundante de força de trabalho barata. Enquanto as actividades de lavra subterrânea (específicas das minas de dimensão paraindustrial ou industrial) alcançaram uma presença média de cerca de $42 \%$ dos operários; a lavra a céu aberto, transporte e esgoto atingiu perto de $22 \%$; a preparação e transformação de minérios cerca de 22\%; os serviços técnicos, oficinas gerais e construções perto de $14 \%$.

Realce para o facto de, no ano de 1939 , um pouco mais de $14 \%$ do operariado formalmente contratado por empresas mineiras ser do sexo feminino. Das 3188 mulheres e raparigas envolvidas, 2619 (81,9\%) exerciam funções na área da preparação e transformação de minérios. Esta presença significativa é tanto mais notória quanto se conhecem alguns dos vectores de enquadramento: proibição legal de mulheres e raparigas exercerem a actividade no subsolo, reprovação social da utilização de mão-de-obra feminina na indústria extractiva em geral, discriminação no acesso ao emprego (sobretudo em época de crise), interesse patronal na contratação de trabalhadoras com salários mais baixos (nomeadamente em tarefas indiferenciadas).

Entre as minas e coutos mineiros de grande dimensão - algumas das quais concessionadas a sociedades que integravam o grupo das maiores empresas com actividade em Portugal Continental -, salientaram-se S. Domingos, Aljustrel e Lousal (sulfuretos maciços, distritos de Beja e Setubal), São Pedro da Cova, Pejão e Cabo Mondego (carvão, distritos do Porto, Aveiro e Coimbra), Panasqueira e Borralha (volfrâmio, distritos de Castelo Branco e Vila Real/ Braga), Gaia (estanho, distritos de Castelo Branco/Guarda), Braçal e Malhada (chumbo, distrito de Aveiro).

Recorrendo, uma vez mais, ao período de 1931 a 1939, verifica-se que S. Pedro da Cova e S. Domingos foram dominantes até 1934: 1571 assalariados ou $22,4 \%$ e 1475 ou $21 \%$, respectivamente, em $1931 ; 1644(25,3 \%)$ e 1320 $(20,3 \%)$ em $1932 ; 1660(25,4 \%)$ e $1248(19,1 \%)$ em $1933 ; 1550(18,2 \%)$ e $1371(16,1 \%)$ em 1934. O Couto Mineiro da Panasqueira evoluiu do quarto para o primeiro lugar desde 1931 e 1932 (527 assalariados ou 7,5\%, 533 ou $8,2 \%$ ) até 1937-1939 (1668 ou 9,7\%, 2457 ou 12,3\%, 3512 ou 14,2\%), preenchendo, também, as seguintes posições intermédias: terceiro com 587 assalariados ou 9\% em 1933, terceiro em 1934 (818 ou 9,6\%), segundo em 1935 (1297 ou 12,3\%), terceiro em 1936 (1199 ou 10,5\%). Ao longo dos 9 anos estudados, as 10 maiores concessões localizadas em Portugal Continental absorveram, assim, entre $81,3 \%$ (1931) e 52,1\% (1939) dos activos mineiros 
oficialmente empregues.

Se pretendermos apresentar um organograma-tipo das minas com um nível de complexidade efectivamente industrial (grande ou média escala), é possível referir os seguintes elementos identificadores: administração, gabinete de estudos e laboratório; armazém e oficinas gerais, construção e reparação, infraestruturas sociais; produção e/ou distribuição de energia; extracção subterrânea (galerias de rolagem, galerias travessas, galerias nos filões, chaminés e poços), transportes interiores e esgoto/tanques de decantação; extracção a céu aberto (cortas, sanjas, trincheiras, poços, lavagem de aluviões) e transporte exterior; escolha e trituração, separação e concentração; transporte e exportação.

Grande parte das outras concessões apresentava níveis tecnológicos e organizativos muito rudimentares. Não existia fornecimento de energia eléctrica, não eram utilizados compressores nem martelos pneumáticos, os únicos motores instalados integravam o sistema de esgoto da mina - cujas águas poluídas não eram alvo de qualquer tipo de tratamento. O minério era apenas lavado e separado manualmente, sendo todas as outras fases do processo de concentração realizadas em oficinas existentes em localidades mais ou menos próximas (propriedade dos concessionários ou de outros empresários e sociedades). Dadas as más condições das vias de comunicação secundárias e/ou a falta de recursos financeiros, como meio de transporte até ao caminho de ferro ou às empresas de camionagem, eram, frequentes vezes, utilizados animais e veículos arcaicos (carroças, barcaças, vaivéns aéreos).

No que diz respeito à nacionalidade dos concessionários, as maiores explorações, responsáveis pelo essencial da produção, foram quase sempre monopolizadas por sociedades mineiras britânicas, belgas, francesas - em alguns casos ou durante conjunturas específicas, também norte-americanas e alemãs. Muitas vezes, essa "apropriação externa" ocorreu após tentativas pouco conseguidas - ou essencialmente especulativas - de gestão por parte de investidores nacionais.

Até meados da década de cinquenta, a grande burguesia portuguesa encontrou-se, no essencial, afastada da exploração dos nossos principais recursos mineiros. Um tal desinteresse derivaria dos fortes investimentos iniciais exigidos, da elevada margem de risco própria da actividade extractiva; dos obstáculos ao estabelecimento de contactos, à consolidação de relações paritárias e estáveis com os potenciais compradores estrangeiros; da escassez de interfaces significativos - a montante e a juzante - com outras indústrias e serviços 
localizados entre nós; da inexistência de políticas consequentes e mobilizadoras, de apoios (directos e indirectos) tendo por objectivo a transformação do sector mineiro num dos pilares de um eventual processo de modernização acelerada da economia e da sociedade portuguesas.

Lembra-se, a título meramente ilustrativo, que, entre 1900 e 1911, por intermédio da Sociedade de Minas de Wolfram em Portugal, Almeida, Silva Pinto \& Comandita, a Henry Burnay \& Companhia (Banco Burnay, SARL a partir de 1925) controlou várias das concessões que, desde 1927, estiveram na base da delimitação do Couto Mineiro da Panasqueira. Provavelmente adquiridas por via hipotecária e apesar dos indícios de que se estaria perante uma grande mina de volfrâmio (mesmo à escala mundial), foram as mesmas vendidas a uma empresa britânica na primeira fase de euforia do tungsténio de corrida aos armamentos e de pré-guerra económica. Desde 1912 até ao início da década de setenta (1973), a sua exploração esteve a cargo de duas sociedades de capitais exclusivamente estrangeiros: a Wolfram Mining and Smelting Company, Ltd. (Londres) e a Beralt Tin \& Wolfram, Ltd. (Londres).

O reconhecimento institucional de grande parte desta mesma hierarquia de peso económico e capacidade tecnológica pode ser encontrado numa circular enviada pela Direcção-Geral de Minas e Serviços Geológicos, no dia 1 de Outubro de 1936, a 10 sociedades mineiras com actividade em Portugal Continental $^{50}$. Depois da promulgação do Decreto n ${ }^{\circ} 26: 974$, de 2 de Setembro de 1936, tratava-se de eleger o representante das empresas do sector extractivo no Conselho Superior de Geologia e Minas (triénio de 1937-1939, com início a 1 de Janeiro de 1937).

Face à inexistência de um organismo corporativo especializado, considerou-se que os "representantes naturais" do patronato mineiro seriam as Mason \& Barry, Ltd., Société Minière Générale de l'Étain, SA, Ervedosa Tin Mines, Ltd., Mines de Borralha, SA, Société Anonyme Belge des Mines d'Aljustrel, Beralt Tin \& Wolfram, Ltd., Portuguese-American Tin Company, Ltd., Companhia das Minas de Carvão de S. Pedro da Cova, SARL, Empresa MíneroMetalurgica, Lda., Companhia de Estanho do Vale do Vouga, SARL. Excepção feita a dois agentes económicos portugueses - um dos quais oriundo do universo do carvão, não-concorrencial em termos de mercado externo -, todos os outros eram maioritária ou totalmente controlados por capital estrangeiro (britânico, francês, belga e norte-americano). 
Por sua vez, as concessões de média dimensão eram divididas entre sociedades e empresários estrangeiros (ingleses, franceses, belgas, holandeses, norte-americanos, alemães) e nacionais, ficando os portugueses com o exclusivo das pequenas minas e das explorações informais - clandestinas ou legalizadas, mas sempre de funcionamento precário. Entre os responsável pelo registo da descoberta de jazigos, quantas vezes a partir de afloramentos ou de escombreiras da época romana, destaque para "populares" das zonas mineiras (pastores, camponeses-mineiros, comerciantes, proprietários dos terrenos, etc.), para quadros técnicos ou empresários de explorações já em actividade.

Algo de semelhante ocorreu, quer com as tecnologias e soluções organizativas, quer com o "pessoal superior" das minas: máquinas e métodos de trabalho, administradores e contabilistas, engenheiros e geólogos estrangeiros nas grandes e médias concessões; máquinas estrangeiras e instrumentos nacionais, engenheiros, engenheiros auxiliares, agentes técnicos de engenharia e condutores portugueses nas médias e pequenas concessões.

Durante o período considerado manteve-se, assim, uma significativa dependência perante a tecnologia e o know how estrangeiros. Verificou-se essa continuidade apesar de o Decreto $n^{\circ} 18: 713$, de 11 de Julho de 1930, obrigar à presença de Directores Técnicos nacionais em todas as minas ou coutos mineiros situados em território "metropolitano"; à revelia das fortes pressões corporativas exercidas pelo Instituto Superior Técnico e Faculdade de Engenharia do Porto, Associação dos Engenheiros Civis Portugueses e Ordem dos Engenheiros; independentemente das veementes críticas de inúmeros publicistas e das (mais conciliatórias) declarações programáticas explicitadas por sucessivos responsáveis governamentais, do aparelho de Estado, na Assembleia Nacional e Câmara Corporativa ${ }^{51}$.

O nível de desenvolvimento atingido, em algumas minas, pelas "lavarias", oficinas gerais, serviços de construção e reparação de edifícios e estradas (próximo da autosuficiência), resultaria de dois tipos de factores. Por um lado, de uma estratégia de controlo directo sobre e de proximidade geográfica das funções complementares da actividade extractiva que se revelassem particularmente lucrativas ou exigentes (no plano técnico, em termos de custos de transporte, etc.). Por outro, da escassez de oferta nacional de qualidade nesse

${ }^{51}$ Cfr. COLP, $2^{\circ}$ Semestre de 1930, p. 275-292 e, sobretudo, C. Arenas Posadas, 1999; R. Bosson, 1977; E. Campos, 1913; A.M. Costa, 1931;A.L.A. Inglês, 1928;M.L. Rodrigues, 1999; L.C. Sola, 1934. 
mesmo âmbito, do esforço para evitar a subordinação face a uma "administração pública ineficaz ou conservadora", a fornecedores sediados em outros países.

Não será, igualmente, arriscado considerar que, na melhor das hipóteses até ao final dos anos cinquenta, permaneceram muito insuficientes na actividade extractiva as condições de trabalho e de vida do operariado; os níveis de segurança e higiene no trabalho; os seguros contra acidentes e doenças profissionais, as modalidades de apoio social aos trabalhadores e suas famílias; os mecanismos de controlo da poluição e de indemnização dos interesses afectados. Tratar-se-ia, no entanto, pelo menos em minas de dimensão industrial, de uma alternativa razoavelmente favorável à escassez de perspectivas de ascensão social, ao desemprego e ao subemprego, às migrações sazonais ou à emigração, à miséria crónica impostos a uma grande percentagem do campesinato.

Em Portugal, as elites político-administrativas e "técnicas" - empresários, engenheiros, médicos, associações patronais e sócio-profissionais, escolas superiores - dispuseram sempre de alguma capacidade de intervenção, entre outras razões porque acompanhavam as mais recentes descobertas científicas e propostas de aplicação tecnológica surgidas a nível internacional. Se acrescentarmos a esta primeira avaliação o constatar de que no nosso país se encontravam instaladas empresas oriundas de algumas das maiores potências industriais, tornam-se ainda mais visíveis as distâncias que separavam o plano das intenções proclamadas do enquadramento jurídico-institucional e, sobretudo, da realidade do dia-a-dia nas concessões e nas aldeias mineiras.

A título de condicionalismos explicativos das discrepâncias em causa, é possível referir, nomeadamente, a instabilidade do sector e a falta de capacidade financeira de muitas empresas, a postura de tipo neo-colonial assumida por sociedades mineiras de capitais estrangeiros e a atitude generalizada de busca do lucro imediato; as insuficiências da legislação e o défice de fiscalização por parte das autoridades. A pobreza e a ausência de tradições de organização/ intervenção cívica e sindical que marcavam as populações camponesas; a acção desmobilizadora e geradora de conformismo protagonizada pelo essencial do clero católico; a repressão patronal e policial ou militar (agravada após o consolidar do Estado Novo) de que eram alvo as mais ou menos embrionárias iniciativas de reivindicação e luta concretizadas pelos trabalhadores.

Reconhecendo-se que a laboração à superfície e a extracção no subsolo implicavam diferentes níveis de desgaste físico e psicológico, de compensação material e valoração simbólica; que eram díspares as probabilidades de invalidez 
ou morte por acidente ou doença profissional, assistiu-se a uma relativa separação entre aquelas duas parcelas do mercado de emprego mineiro. Tendencialmente, enquanto a mão-de-obra oriunda de segmentos 'remediados' do campesinato ou de zonas rurais menos desprovidas de recursos (económicos e relacionais) escolhia o primeiro tipo de actividades, a força de trabalho mais proletarizada ou originária de localidades ultra-periféricas era relegada para a lavra subterrânea.

Em termos gerais e paralelamente ao que sucedia com os quadros técnicos de formação superior e média, poderá afirmar-se que funcionários ("colarinhos brancos"), chefias intermédias e operários qualificados de superfície - no que diz respeito aos "colarinhos azuis" - tinham acesso a contratos anuais de trabalho e a salários mensais. Os outros trabalhadores manuais (a esmagadora maioria dos activos mineiros) eram forçados a aceitar ou encontravam vantagens em regimes de precaridade extrema: à jorna ("geira") ou de empreitada ("à tarefa"), recebendo - no fim da semana, da quinzena ou do mês - de acordo com os dias preenchidos ou com as quantidades de minério entregues.

Desde a Primeira República que, nos 6 dias úteis por semana - em regime normal ou em laboração contínua -, o horário de trabalho mineiro constava de 7 horas para os empregados de escritório e de 8 horas para todos os outros assalariados (com 1 hora de intervalo). Frequentemente, obrigava-se à ampliação do período de actividade, quase sempre sem o correspondente pagamento de horas extraordinárias. Por influência do mundo rural envolvente e aparente adesão de ambas as partes interessadas, aos grupos de indivíduos "à tarefa" aplicavam-se as normas consuetudinárias do "trabalho de sol a sol".

Para o preencher das 8 horas de laboração tinha-se em conta, não a presença junto aos escritórios ou à boca da galeria de entrada, mas a capacidade para iniciar de imediato as tarefas que haviam sido distribuídas. Em concessões de grande dimensão - com percursos ascendentes e descendentes que chegavam a atingir cerca de 30 minutos -, uma tal lógica implicava que os operários do subsolo se encontravam ocupados até mais $\mathbf{1}$ hora por dia, que a pausa a meio do turno não podia ser aproveitada para uma vinda à superfície. Se, em algumas explorações, a remuneração-base era complementada com prémios de assiduidade e de produtividade, na generalidade das situações os mineiros eram obrigados a pagar os gasómetros $e$ o inerente "carboreto", único método de iluminação disponibilizado.

Uma outra 'regra' comum aos operários mineiros em situação de assalariato 
era a da frequente aplicação de penalizações de ordem material. Decididas pelos capatazes - nos casos tidos como mais graves, pelos engenheiros, administradores ou empresários - e anotadas nas "folhas de serviço" respectivas, assumiam a forma de multas (descontadas na jorna), proibições de laborar por um ou mais dias, bloquear da progressão na 'carreira', despedimento. Contratados individualmente ou em grupos estruturados ("sociedades" ou "ranchos") e com liderança própria ("empreiteiros" ou "contratistas"), os tarefeiros eram, por sua vez - à semelhança do que acontecia nas actividades agrícolas -, responsáveis pela compra e manutenção dos instrumentos de trabalho, bem como pela aquisição de todos os materiais necessários à concretização de rebentamentos (ou "pegas de fogo").

Verificou-se uma hierarquização descendente de estatutos profissionais e remunerações que ia dos funcionários aos trabalhadores não-qualificados, passando pelas chefias intermédias e/ou operários qualificados de superfície, guardas, operários qualificados de subsolo. Se, face aos outros sectores industriais, os salários mineiros eram, em geral, inferiores, os mesmos apresentavam alguma superioridade perante as remunerações da agricultura. Mulheres, rapazes e raparigas auferiam entre $65 \%$ e $50 \%$ dos ordenados dos trabalhadores adultos do sexo masculino a desempenhar funções idênticas.

Elementos de protecção individual como os capacetes (de cabedal), máscaras, óculos e luvas eram pagos pelos assalariados e tinham carácter facultativo, o que acentuava a tendência para a sua utilização restrita (quase nula). Ainda não se recorria, tanto a vestuário e calçado adaptados à actividade mineira, como à rotina do banho e da mudança de roupa, no fim de cada dia de trabalho, em balneários localizados junto às áreas de extracção ou às instalações de separação e concentração.

Apesar de a introdução de martelos pneumáticos ter implicado um aumento substancial da incidência de problemas respiratórios entre os marteleiros e ajudantes, só no final dos anos trinta começaram a ser utilizadas perfuradoras de ar comprimido com injecção de água. Embora a generalidade das tarefas extractivas, concretizadas manualmente, resultasse na libertação de grandes quantidades de poeira, não se procedia à humidificação das frentes de desmonte ou dos inertes através de borrifadores; não se tentava reduzir ao mínimo as situações de arrastamento ou queda de escombro; não foram instalados mecanismos de "controlo dos empoeiramentos" (de medição da quantidade de partículas em suspensão) ou de aspiração/captação de poeiras; eram quase- 
inexistentes ou pouco eficazes os sistemas artificiais de ventilação, indispensáveis quando as redes de galerias atingiam profundidade e extensão significativas.

Mesmo face à nocividade extrema, quer das ondas de poeira que se seguiam às explosões, quer dos gazes de enxofre, arsénio e outros libertados durante as operações metalúrgicas integrantes dos processos de separação e concentração dos minérios, mantinham-se distâncias físicas e/ou intervalos de tempo demasiado curtos entre as "pegas de fogo" e a retoma do trabalho ou a interrupção "para a janta" tomada no subsolo. Por outro lado, as oficinas em causa - lavarias quando localizadas dentro de uma concessão mineira - não eram edificadas, organizadas e equipadas de modo limitar os riscos de intoxicação. Algumas queixas surgiram, tanto da parte de operários directamente envolvidos, como de vizinhos de unidades de transformação (separadoras) implantadas em povoações.

Para além das contingências inerentes às actividades económicas em geral, uma elevada percentagem dos acidentes verificados no sector mineiro teria origem em características estruturais, no tipo de relações laborais adoptadas, em erros de planeamento ou fiscalização, em comportamentos individuais desadequados, etc. Entre as situações mais frequentes, causadoras de incapacidades - ligeiras, temporárias, permanentes (parciais ou totais) - ou de morte, lembram-se: quedas de trabalhadores, desprendimento ou deslizar/rolar de blocos de pedra, desabamentos, rebentamentos não-controlados ou explosões retardadas, disfunções ou utilização inadequada de instrumentos e máquinas ou de sistemas de transporte de inertes, choques eléctricos e intoxicações agudas (o "tufo" em galerias subterrâneas, "fumos" em lavarias ou separadoras).

Com origem no esgoto das minas, nas operações de tratamento dos minérios - efectuadas em termos artesanais ou industriais, a céu aberto ou em lavarias/ separadoras -, na escorrência das escombreiras (durante ou após o fim da actividade extractiva), compostos químicos nocivos contaminaram ribeiras e rios, terrenos e lençóis friáticos. Eram afectadas a água consumida por pessoas e gado, a agricultura (de sequeiro e, antes de mais, de regadio), a pecuária e a pesca. Mau grado o facto de a legislação obrigar à presença de dispositivos de controlo de danos - tanques de decantação, reaproveitamento dessas mesmas águas residuais nas lavarias, filtros nas chaminés, lagoas de lamas ou bacias de rejeitados, silos para anidrido arsenioso, barreiras de contenção dos aterros de ganga ou estéril acumulados, etc. -, em muitos casos aqueles não existiam ou tornavam-se insuficientes. 
Se, quase por definição, as "explorações paralelas" e as pequenas concessões ignoravam quaisquer procedimentos de salvaguarda ambiental, as minas de média e grande dimensão foram concretizando algumas das medidas técnicas exigíveis. Assumidas por moto próprio ou em resultado de queixas de particulares e da acção fiscalizadora do aparelho de Estado, as iniciativas em causa revelaram-se, por sua vez, ou precárias desde o início, ou inadequadas à medida que aumentava o ritmo de extracção, separação e concentração.

Num outro âmbito, a actividade mineira introduzia vectores de atrito potencial com o universo rural em que se localizava ao desviar nascentes e cursos de água, ao ocupar áreas agricultáveis ou florestáveis; quando destruía culturas, árvores e pastos, quando fazia perigar a fruição dos baldios pelos compartes; sempre que colocava em risco a estabilidade de edifícios e vias de comunicação pré-existentes. Aumentando a procura de trabalho (precário e temporário embora) e garantindo remunerações ligeiramente superiores mesmo à mão-de-obra indiferenciada.

A efectiva acção desagregadora da actividade extractiva, a natureza e dimensão dos protestos e exigências apresentados dependeram, no entanto, dos interesses em presença, do estatuto dos agentes económicos envolvidos, das diferentes tendências conjunturais vigentes ao longo dos anos. Habitualmente realizadas pelos donos ou rendeiros das parcelas, a lavra informal ou a exploração legal de aluviões eram concretizadas de forma a possibilitar a retoma das valências agrícola ou pecuária assim que terminasse cada fase de procura excepcional de concentrados.

Verificando-se que as indemnizações entregues pelos concessionários eram, por norma, tardias e muito insuficientes quando se tratava de terrenos férteis de uso permanente, o mesmo se não pode afirmar de propriedades com solo pobre e raramente utilizadas. Algo de idêntico ocorria sempre que, devido a ausência de acordo entre as partes, era solicitada a expropriação de terrenos para a construção de edifícios ou outras estruturas de apoio à mineração: das estações geradoras de ar comprimido aos bairros operários, passando por sistemas de cabo aéreo, armazéns e oficinas, lavarias, residências de quadros superiores e funcionários, etc.

Muito ou pouco exigidas pelos assalariados - nas concessões, influenciados pela "acção social católica", pelo habitus sindical (livre e, depois, corporativizado), por organizações políticas e imprensa (legais ou clandestinas), pelos exemplos estrangeiros (nomeadamente espanhóis) -, algumas das "regalias 
complementares" foram impostas através da legislação e da praxis administrativa, 'concedidas' por decisão patronal ou 'sensibilização' governamental e do aparelho de Estado.

Refira-se, antes de mais, a ausência de cobertura em termos de "previdência social" (pensões, subsídios, reformas) para inválidos por acidente ou doença de origem não-profissional, ex-trabalhadores idosos, viúvas e órfãos ou outros dependentes. Esse mesmo vazio derivou, tanto do boicote empresarial às soluções de carácter tendencialmente público e universal assumidas pelo poder republicano no imediato pós-Primeira Grande Guerra (Seguro social obrigatório contra invalidez, velhice e sobrevivência; Instituto de Seguros Sociais Obrigatórios e de Previdência Geral), como à lógica privatizadora e 'gradualista', facultativa e 'pragmática' (ou casuística) adoptada pelo Estado Novo.

Quanto aos esforços de atenuação das dificuldades resultantes dos frequentes períodos de inactividade, para além de medidas indirectas - limitação do recurso a mão-de-obra estrangeira, preferência por bens e serviços nacionais, reforço do proteccionismo pautal e colonial, lançamento de programas de obras públicas -, a Ditadura Militar e o Estado Novo criaram, junto do Ministério das Obras Públicas e Comunicações, o Comissariado do Desemprego, responsável pela gestão do Fundo de Desemprego, de modalidades de rastreio e colocação de desempregados.

Apesar de a todos os assalariados e tarefeiros do comércio e indústria serem descontados $2 \%$ do conjunto dos rendimentos obtidos por conta de outrem, de os correspondentes patrões serem obrigados a entregar esses montantes ao Fundo, acrescidos de $1 \%$ do valor das remunerações pagas, o Comissariado apenas utilizava as verbas em causa para custear a sua própria existência, programas de obras públicas e incentivos à contratação por privados de outros desempregados inscritos nos serviços oficiais competentes. Independentemente de quase $67 \%$ dos recursos financeiros acumulados provirem dos trabalhadores activos, o subsídio de desemprego era encarado como "imoral e gerador de parasitismo".

Perante a exiguidade dos mecanismos definidores do que viria a ser o "Estado providência", dada a quase-inexistência das formas de concertação específicas do capitalismo fordista, nas situações de quebra (temporária ou definitiva) da capacidade produtiva ou do "índice de empregabilidade", restava aos mineiros, como alternativa a níveis extremos de pobreza, o valorizar da "sociedade providência". Citam-se, antes de mais, os apoios familiares e comunitários (no 
espaço mineiro e/ou rural), a pluriactividade, o refúgio na "economia paralela", a migração (sazonal e de longo prazo) ou a emigração, a 'caridade' por parte das elites tradicionais ou dos concessionários.

Relativamente às maiores empresas em presença, a "benemerência patronal" consistiu na atribuição de pensões de reforma (sobrevivência) e na possibilidade de continuação de usufruto gratuito de casa com água, iluminação e lenha para um limitado número de operários com grande antiguidade, modelarmente eficazes e "respeitadores das hierarquias" - regalias extensíveis às viúvas e filhos menores. Na contratação prioritária de esposas ou viúvas, filhos ou filhas de ex-trabalhadores sem demasiadas informações negativas nas fichas individuais (ou "folhas de serviço"). Na passagem de alguns mineiros silicóticos ou com outras formas de invalidez parcial para tarefas de fiscalização ou guarda a céu aberto.

Em quase todas as pequenas explorações, os serviços e edifícios de cariz social limitavam-se, na melhor das hipóteses, a parte ou ao conjunto dos seguintes elementos: residências individuais (com pequenos jardins) para administradores, engenheiros, funcionários, capatazes ou guardas, etc; pequenas fileiras de casas para operários com as respectivas famílias - 2, 3 ou 4 divisões consoante o número de filhos; camaratas ("quartéis" ou "casas da malta") para operários solteiros e/ou deslocados; cantina com refeições a preços controlados; abertura e manutenção ou alargamento de estradas ou caminhos e transporte rodoviário para escoamento de minérios, entrada de produtos e deslocação de pessoas.

Num plano intermédio, foram sendo assegurados, a título gratuito ou com preços moderados (por vezes subsidiados), residências para o "pessoal superior e intermédio" - incluindo mobiliário, "criadas de dentro" e lenha, caiação dos edifícios e outras reparações -, casas e camaratas para operários, iluminação e água (canalizada ou em fontanários); hospedarias (ou "messes") para funcionários solteiros, incluindo alojamento, alimentação e "criadas de dentro"; padarias, cantinas (ou "cozinhas económicas") e restaurantes, armazéns de bens de consumo; lavatórios junto de oficinas e lavarias, apoio médico generalista para os assalariados e famílias, bem como para os tarefeiros - em regime de avença, sob a forma de uma ou duas visitas semanais e de "chamadas de emergência"; estradas e transportes ferroviários, distribuição de energia eléctrica e correio, ligações telefónicas e serviço de telegramas.

De acordo com o que seria de esperar e mau grado as insuficiências apontadas 
mesmo por entidades oficiais, apenas as grandes minas acumularam, ao longo dos anos, um leque globalizante de valências sociais. Para além dos aspectos já focados no que concerne a outras concessões - agora em quantitativos mais amplos -, identificou-se a existência de assistência médica e de enfermagem permanentes; de "blocos sanitários" (retretes, lavadouros, chuveiros), esgotos e fossas, recolha de lixo; de clubes recreativos e desportivos, patrocinados e tutelados pelas companhias - cedência de terrenos, custeio de instalações, atribuição de subsídio anual, aprovação da direcção e das actividades.

Implantaram-se, ainda, prémios monetários para os mineiros que ultrapassassem as metas diárias de produção em cada frente de desmonte ("gratificação de perfuração", "gratificação de avanço") e, em geral, para os trabalhadores que não "faltassem injustificadamente" ("bónus de assiduidade" nos "meses limpos"); escolas primárias ou "postos escolares" oficiais, sendo os edifícios e o equipamento, as habitações dos professores ou dos "regentes escolares" (com água, luz e lenha) garantidos pelas empresas.

Facilitou-se, igualmente, o cultivo de pequenas hortas por parte dos trabalhadores residentes, com as famílias, nas localidades exclusivamente mineiras; a abertura de cooperativas de consumo e de "comércios privados" (mercearias e tabernas), a realização de feiras semanais. Estruturaram-se sistemas de compras a crédito nos "armazéns de víveres" das companhias - mediante registo em caderneta e por "adiantamento" da remuneração.

O acompanhamento religioso católico (missa dominical e sermão, confessionário e comunhão geral, baptizados, casamentos e funerais, cataquese e crisma, procissões e pregações), da responsabilidade de capelões privativos ou de sacerdotes das paróquias vizinhas, era seguido com particular atenção pelas dioceses envolvidas e apoiado pelas companhias, as quais garantiram a construção e paramentação de capelas, as negociações com as autoridades eclesiásticas, a participação de "pessoal superior" de nacionalidade portuguesa. Manteve-se, também, um calendário de celebrações profanas e religiosas envolvendo quadros dirigentes e famílias, sacerdotes, docentes, trabalhadores e famílias: missa e procissão, desfile de banda e fogo de artifício, entrega de prémios e/ou prendas e baile, competições desportivas, etc.

Sediada em Lisboa e responsável pela edição do boletim Indústria Portuguesa (1928 e seguintes), a Associação Industrial Portuguesa representava, antes de mais, o patronato do centro-sul e sul do país. Integrou uma "Secção de Minas" que manteve actividade permanente no que diz respeito a este universo 
económico: realização de conferências, divulgação de informações técnicas e de propostas, apresentação de críticas e reivindicações ao poder político, participação no alterar do ordenamento jurídico, etc.

Quanto à Associação Industrial Portuense, que publicou $O$ Trabalho Nacional (depois A Indústria do Norte), estruturou no seu âmbito uma "Classe de Minas e de Tratamento de Minérios" que assegurou uma intervenção menos regular, sobretudo voltada para os subsectores do volfrâmio e do estanho e centrada nas fases da Primeira Grande Guerra, "Crise de 1929", Segunda Guerra Mundial e Guerra da Coreia. Limitou-se, nos outros períodos, a apoiar as iniciativas da congénere lisboeta e a transmitir dados informativos (estatísticas, legislação, novos conhecimentos científicos ou soluções tecnológicas) ${ }^{52}$.

Inversamente ao ocorrido nos subsectores das pirites, do carvão e da lousa, os universos do volfrâmio, estanho, ferro, manganés, chumbo, etc., não deram origem a quaisquer associações de socorros mútuos, cooperativas de consumo ou "associações de classe" - Sindicatos Nacionais após 1933/1934. Tratou-se, provavelmente, de uma consequência da precaridade das explorações, semiconsolidação das comunidades mineiras, preservação dos laços familiares e sociais globais com o mundo rural, menores níveis de conflitualidade sóciopolítica, reprodução dos valores e das hierarquias tradicionais (religiosidade, mundividência pré-capitalista e pré-cívica, aceitação da tutela das elites locais em paralelo com modalidades embrionárias de paternalismo empresarial).

\section{Balanço provisório ${ }^{53}$}

Apesar de todos os debates e tomadas de posição, das pressões exercidas pelas sucessivas correntes "regeneradoras e modernizadoras" mais ou menos industrialistas, pelo menos até 1953, os interesses dominantes acabaram por garantir a permanência de uma especialização no exportar de minérios, quase exclusivamente semi-transformados, para os países mais industrializados. Bloquearam-se, assim, os efeitos potenciadores que o sector extractivo poderia ter tido em relação ao aparelho de Estado, ao conjunto da economia e da sociedade portuguesas.

s2 Apenas em 18 de Outubro de 1970, na etapa marcelista do Estado Novo, um Alvará do Ministério das Corporações e Previdência Social formalizou a criação do Grémio Nacional das Indústrias Mineiras.

s3 Cfr., nomeadamente, H. Alves, 2000; C. Arenas Posadas, 1999; R. Bosson, 1977; L.R. Costa, 2000; P. Guimarães, 2001; J. Nash, 1993; D. Reid, 1985; F. Rosas, 2000; A.J. Telo, $2000 b$. 
Verificaram-se níveis elevados de integração da actividade mineira no mercado mundial (superiores aos do todo "metropolitano e colonial"), de subordinação da mesma às estratégias de empresas sediadas em nações centrais e semi-periféricas. Destacavam-se a Grã-Bretanha, a França e a Bélgica, compradoras de matérias-primas de baixo valor acrescentado e com termos de troca tendencialmente decrescentes. Proprietárias das melhores concessões e das maiores empresas; fornecedoras de capitais e combustíveis, das tecnologias e métodos organizativos, dos técnicos mais eficazes. Detentoras do monopólio da exportação, comercialização e transformação industrial; principais consumidoras dos produtos finais; com acesso a fornecedores alternativos em situação tanto ou mais periférica e dependente.

Constata-se a limitada capacidade de o sector extractivo contribuir para um desenvolvimento global e sustentado do país por quase não terem existido transformação e incorporação industrial dos minérios (excepção feita ao carvão, não competitivo nos mercados internacionais). Dada a não-ultrapassagem de bloqueios estruturais em termos de transportes, fontes de energia, qualificação da mão-de-obra; a escassa multiplicação das ligações com sectores 'complementares' de actividade e concretização de estratégias não-absentistas de investimento dos capitais gerados. Face à inexistência de discriminação positiva em favor das zonas periféricas produtoras tendo por objectivo a atenuação das assimetrias regionais.

Quando, a partir de um mundo rural dominante mas, no essencial, arcaico e bloqueado, chegaram a estruturar-se "comunidades mineiras", tratou-se de espaços sócio-económicos e culturais mono-dependentes, com baixa qualificação global da mão-de-obra, maiores dificuldades de reconversão profissional, limitada capacidade para potenciar o surgimento e consolidação de outras actividades económicas. Esse mesmo impasse verificou-se apesar de algum paternalismo patronal, da imigração de profissionais diferenciados (administradores, engenheiros, geólogos, contabilistas, etc.), do acesso a uma economia monetária, do desenvolvimento de laços de solidariedade e de um embrião de consciência de classe entre os operários.

Nas áreas de instalação da generalidade das explorações mineiras (interiores e montanhosas, com baixa densidade populacional, subdesenvolvidas), observa-se, pois, que, no médio e longo prazos, as vantagens resultantes da presença da actividade extractiva não foram muito significativas; que o balanço entre aspectos positivos e negativos esteve longe de ser definitivamente favorável. Tratou-se, por um lado, de uma fonte complementar de rendimento para 
populações que até então viviam apenas de uma agro-pastorícia de semi-subsistência, de trabalho eventual para proprietários absentistas, de migrações sazonais ou da emigração.

Os funcionários e operários mineiros começaram, também, a aceder, pelo menos nas minas de dimensão industrial, a níveis de consumo e a algumas regalias sociais inexistentes no universo camponês circundante: horários/ cadências de trabalho pré-definidos e salário regular, habitação e aquecimento, abastecimentos e alimentação, saúde e educação, diversões e vida comunitária de tipo urbano. Ocorreram, ainda, melhorias parciais no que concerne a vias de comunicação (estradas, pontes, caminho-de-ferro, carreiras de camionetas), energia eléctrica, fixação ou atracção de pessoas e de actividades económicas complementares.

Em sentido inverso, deram-se o desvio e a poluição de nascentes e cursos de água, a ocupação e o contaminar de terrenos durante e após o encerramento das explorações; percentagens significativas de mineiros incapacitados ou mortos devido a acidentes e doenças profissionais (com destaque para a silicose). Resultou o segundo grupo de consequências, entre outros factores, da sobreinstabilidade do universo mineiro, de um empenhamento exclusivista na maximização dos lucros por parte dos agentes económicos, da quase-ausência de intervenção por parte "das autoridades", da limitada consciência sócioprofissional e organização sindical dos trabalhadores.

Mesmo durante os períodos de "normalidade" ou "euforia" dos mercados internacional e nacional de minérios, tendeu-se para o consumo sumptuário, o investimento nas actividades tradicionais e na formação escolar, a migração para as cidades e a transferência para o sector terciário. Assistiu-se, sobretudo, à apropriação do essencial das mais-valias geradas pelas sociedades mineiras, sistema bancário e Estado - ou seja, por Lisboa, Porto, Londres, Paris, Bruxelas, etc. Nas recorrentes etapas de depressão e crise, desemprego e desactivação, prevaleceu a estratégia de regresso ao mundo rural ou às zonas urbanas de origem. 


\section{DOCUMENTAÇÃO E BIBLIOGRAFIA}

AIRES-BARROS, Luís, "Os minerais e suas eventuais acções agressivas sobre o organismo humano", Boletim de Minas, vol. 20, $\mathbf{n}^{\circ}$ 2, Abril-Junho de 1983, p. 67 76.

ALMEIDA, Augusto Farinas de, "A indústria mineira na economia nacional", Revista da Faculdade de Engenharia, vol. XII, n $^{\circ}$ 1, Julho de 1946, p. 1-16.

ALVES, Helena, Mina de São Domingos. Génese, formação social e identidade mineira, Mértola, CAM, 1997.

ALVES, Helena, "Um século de mineração no Alentejo", História, III Série, Ano XXII, $n^{\circ}$ 31, Dezembro de 2000, p. 50-56.

ANDRADE, Costa, "Relatório do inquérito radiográfico da silicose na indústria mineira em 1961", Boletim de Minas, Nova Série, ${ }^{\circ}$ 17, 1962, p. 1-63.

Anuário Estatístico de Portugal [1930] e Anuário Estatístico [1940].

ARENAS POSADAS, Carlos, Empresa, mercados, mina y mineros. Rio Tinto (18731936), Huelva, UH, 1999.

Arqueologia e Museologia Mineiras. Actas do Seminário, Lisboa, IGM, 2000.

Boletim de Minas [1911-1939].

BOSSON, Rex e VARON, Bension, The mining industry and the developing countries, Nova Iorque, World Bank/Oxford University Press, 1977.

CABRAL, José Augusto César das Neves, Estatística mineira (ano de 1882), Lisboa, IN, 1886.

CAMPOS, Ezequiel de, A conservação da riqueza nacional. A grei, os minerais, as matas, os rios, Porto, s.e., 1913.

CARNEIRO, Fernando Soares e LIMA, Manuel António Brandão da Cunha, "Acidentes mortais nas minas portuguesas durante o período de 1947 a 1953", Estudos, Notas e Trabalhos do Serviço de Fomento Mineiro, vol. XI, fasc. 1/2, 1956, p. 1-26.

CARNEIRO, Fernando Soares, "A riqueza da indústria extractiva metropolitana. Do passado, do presente e das perspectivas do futuro - algumas sugestões para a sua necessária valorização", Estudos, Notas e Trabalhos do Serviço de Fomento Mineiro, vol. XIII, fasc. 3/4, 1959, p. 65-215.

CARNEIRO, Fernando Soares, "A silicose e as minas", Estudos, Notas e Trabalhos do Serviço de Fomento Mineiro, vol. XV, fasc. 1/2, 1961, p. 51-78.

CARNEIRO, Fernando Soares, Potencialidades minerais da metrópole. Base firme de desenvolvimento do país, Lisboa, ME, 1971.

CARVALHO, A.M. Galopim de, Sopas de pedra, Lisboa, Gradiva, 2000, vol. I.

CERDEIRA, Maria da Conceição e PADILHA, Maria Edite, As estruturas sindicais portuguesas. Uma análise evolutiva (1933 a Abril de 1987), 3 volumes, Lisboa, MESS, 1988.

CERDEIRA, Maria da Conceição e PADILHA, Maria Edite, O movimento associativo patronal português (1834 a 1994), Lisboa, MTS, 1998. 
X Congresso Internacional de Medicina do Trabalho (Lisboa, 9 a 15 de Setembro de 1951), 1 folheto e 5 volumes, Lisboa, s.e., 1951.

Congresso Internacional sobre Património Geológico e Mineiro. Actas, Lisboa, IGM, 2002.

I Congresso Médico Nacional dos Desastres do Trabalho (Lisboa, Novembro de 1938), Lisboa, s.e., 1938.

COSTA, Artur Mendes da, $O$ ensino elementar de minas em Portugal, Porto, s.e., 1931.

COSTA, Luís Rodrigues da e LEITE, Mário R. Machado, "A recuperação ambiental de áreas mineiras degradadas nas políticas de integração da indústria e ambiente do Ministério da Economia", Boletim de Minas, vol. 37, ${ }^{\circ}$ 3, Julho-Setembro de 2000, p. 167-171.

CUSTÓDIO, Jorge e BARROS, G. Monteiro de, O ferro de Moncorvo $e$ o seu aproveitamento através dos tempos, Moncorvo, Ferrominas, 1984.

CUSTODIO, Jorge, "As minas abandonadas do ponto de vista da arqueologia mineira e industrial", Boletim de Minas, vol. 30, $\mathrm{n}^{\circ}$ 2, 1993, p. 73-83.

FONSECA, Carlos da, História do movimento operário e das ideias socialistas em Portugal, 4 volumes, Mem Martins, Publicações Europa-América, s.d.

FONSECA, Fernando Vasconcelos da, "A indústria extractiva e problemas que se deparam ao médico do trabalho", Boletim de Minas, vol. 1, $\mathbf{n}^{\circ}$ 1, Janeiro-Março de 1964, p. 7-14.

FONSECA, Fernando Vasconcelos da, "Considerações sobre higiene e segurança em minas", Boletim de Minas, vol. 3, $n^{\circ}$ 2, Abril-Junho de 1966, p. 61-69.

FREIRE, Dulce, "A febre do volfrâmio", História, III Série, Ano XXIII, n 37, Julho/ Agosto de 2001, p. 38-43.

GARCIA, João Carlos, A navegação no Baixo Guadiana durante o ciclo do minério (1857-1917), 2 volumes, Porto, 1996 (policopiada).

GARCIA, Ricardo, "As minas que envenenam o Alentejo", Público ("Pública"), 21 de Junho de 1998, p. 18-26.

GASPAR, Filomena, "As minas de ouro do Poço Redondo", Boletim Cultural [CMT], $n^{\circ}$ 17, Março de 1992, p. 139-195.

GASPAR, Orlando C, "História da mineração dos depósitos de sulfuretos maciços vulcanogénicos da faixa piritosa portuguesa", Boletim de Minas, vol. 35, $\mathbf{n}^{\circ}$, Outubro-Dezembro de 1998, p. 401-414.

GESTA, Serafim, Operários da morte, 2 volumes, Porto, s.e., 1978.

GESTA, Serafim, Minas de São Pedro da Cova. Um grito rompe o silêncio, 2 volumes, Porto, s.e., 1981.

GUERREIRO, Luís, Medicina legal corrente nos desastres do trabalho, Lisboa, s.e., 1940.

GUERREIRO, Luís, O problema da silicose nos seus aspectos geral e português, Lisboa, s.e., 1952. 
GUIMARÃES, Paulo, Indústria, mineiros e sindicatos. Universos operários do Baixo Alentejo (dos finais do século XIX à primeira metade do século XX), Lisboa, ICS, 1989.

GUIMARÃES, Paulo, "A intervenção do Estado Novo na indústria mineira: a criação do Serviço de Fomento Mineiro", Boletim de Minas, vol. 32, n 3, 1995, p. 203 215.

GUimarães, Paulo, "As minas portuguesas do Antigo Regime ao liberalismo", Arqueologia \& Indústria, $\mathrm{n}^{\circ}$ 2/3, 1999/2000, p. 53-80.

GUIMARÃES, Paulo, Indústria e conflito no meio rural. Os mineiros alentejanos (1858-1938), Évora, Edições Colibri, 2001.

INGLÊS, António Lobo d'Aboim, As indústrias extractivas em Portugal. Conferência, Lisboa, AIP, 1928.

LAGE, Maria Otília Pereira, Wolfram = volfrâmio: terra revolvida, memória revolta. Para uma análise transversal da sociedade portuguesa (anos 1930-1960), 2 volumes, Braga, 2000 (policopiado).

LEAL, Manuel Vaz, As Minas da Panasqueira. Vida e história (ano de 1945, Bodas de oiro), Lisboa, Portugália Editora, 1945.

LEAL, Transmontano, Minérios e minas, Lisboa, s.e., 1942.

LIMA, Manuel António Brandão da Cunha, "Acerca da poluição das águas", Boletim de Minas, Nova Série, ${ }^{\circ}$ 6, 1960a, p. 5-9.

LIMA, Manuel António Brandão da Cunha, "Pneumoconioses. Sua prevenção e protecção ao doente profissional", Boletim de Minas, Nova Série, $\mathbf{n}^{\circ} 7,1960 \mathrm{~b}$, p. 3$-5$.

LIMA, Manuel António Brandão da Cunha, "Acidentes e doenças profissionais. A recuperação dos operários afectados", Boletim de Minas, Nova Série, $\mathbf{n}^{\circ}$ 10, 1961, p. 8-10.

LOUÇÃ, António, Hitler e Salazar: comércio em tempos de guerra (1940-1944), Lisboa, Terramar, 2000.

LOURENÇO, Cristina, "Regime jurídico da prospecção e da exploração mineira em Portugal", Boletim de Minas, vol. 34, n 2, Abril-Junho de 1997a, p. 131-146.

LOURENÇO, Cristina, "Encargos tributários legais e royalties na exploração mineira", Boletim de Minas, vol. 34, $\mathrm{n}^{\circ}$ 2, Abril-Junho de 1997b, p. 147-153.

MATIAS, Maria Goretti, "Inventário da imprensa patronal (1850-1970)", Análise Social, $3^{a}$ Série, vol. XXIII, $n^{\circ}$ 99, $1987\left(5^{\circ}\right)$, p. 1019-1944.

MC DIVITT, James, "O abastecimento da Europa em minérios", Boletim de Minas, Nova Série, $n^{\circ} 16,1962$, p. 1-6.

MENDES, Fernando Mello, "Os antigos métodos de desmonte das Minas da Panasqueira", Boletim de Minas, vol. 30, n 4, 1993, p. 329-352.

MENDES, José M. Amado, "Cabo Mondego (Figueira da Foz): exploração mineira e indústria", Arqueologia Industrial, III Série, vol. II, n 1/2, 1998, p. 5-21.

MENDES, José M. Amado e RODRIGUES, Manuel Ferreira, História da indústria portuguesa, Mem Martins, AIP/Publicações Europa-América, 1999. 
Minas concedidas no Continente desde Agosto de 1836 a Dezembro de 1962. Lista cronológica e índice alfabético, Lisboa, ME, 1963, 2" edição.

Mineral potential of Portugal, Lisboa, IGM, 1998.

MONTEIRO, J. Gouveia Monteiro, "Silicose pulmonar", Jornal do Médico, vol. XI, $n^{\circ}$ 283, 26 de Junho de 1948, p. 3-14.

NASH, June, We eat the mines and the mines eat us. Dependancy and exploitation in bolivian tin mines, Nova Iorque, Columbia University Press, 1993.

NEVES, Fernando Paulouro e REIS, Daniel, A guerra da mina. Os mineiros da Panasqueira, Lisboa, Edições A Regra do Jogo, 1979.

NOGUEIRA, Augusto de Melo, "Elementos para o estudo da indústria mineira em Portugal nos anos de 1930 a 1939", Boletim de Minas, 1939, p. 3-90.

NUNES, Ana Bela, População activa e actividade económica em Portugal dos finais do século XIX à actualidade, Lisboa, 1989 (policopiado).

NUNES, Guida, Lavradores de volfrâmio, Montalegre, CMM, 1995.

NUNES, João Paulo Avelãs, "Portugal, Espanha, o volfrâmio e os beligerantes durante e após a Segunda Guerra Mundial", Revista Portuguesa de História, t. XXXIII, 1999, vol. II, p. 789-823.

NUNES, João Paulo Avelãs, "Volfrâmio", MÓNICA, Maria Filomena e BARRETO, António (coord.), Dicionário de História de Portugal. Suplemento, Porto, Livraria Figueirinhas, 2000a, vol. 9, p. 601-604.

NUNES, João Paulo Avelãs, "Volfrâmio português e ouro do Terceiro Reich durante a Segunda Guerra Mundial (1938-1947)", Vértice, II Série, ${ }^{\circ}$ 94, Março/Abril de 2000b, p. 42-59.

OLIVEIRA, J.M. Santos, "Algumas reflexões com enfoque na problemática dos riscos ambientais associados à actividade mineira", Estudos, Notas e Trabalhos do Instituto Geológico e Mineiro, t. 39, 1997, p. 3-25.

PATRIARCA, Maria de Fátima, A questão social no salazarismo, 2 volumes, Lisboa, IN-CM, 1995.

PEREIRA, José Jorge Álvares, Riquezas mineralógicas de Barroso e sua história, Montalegre, CMM, 1984.

PEREIRA, Miriam Halpern, "As origens do Estado Providência em Portugal: as novas fronteiras entre público e privado", Ler História, n 37, 1999, p. 45-61.

PIMENTEL, Irene, "A assistência social e familiar do Estado Novo nos anos 30 e 40", Análise Social, vol. XXXIV, ${ }^{\circ}$ 151/152, Inverno de 2000, p. 477-508.

RAMOS, José Luís Bonifácio, $O$ regime e a natureza jurídica do direito dos recursos geológicos dos particulares, Lisboa, Lex - Edições Jurídicas, 1994.

REGO, Miguel e NASCIMENTO, Paulo Jorge (coord.), Mineração no Baixo Alentejo,2 volumes, Castro Verde, CMCV, 1996-2002.

REID, Donald, The miners of Decazeville. A genealogy of deindustrializatrion, Cambridge (Massachusets), Harvard University Press, 1985.

Relatório dos Serviços de Minas relativo ao ano de 1910, Lisboa, IN, 1912.

REZOLA, Maria Inácia, O sindicalismo católico no Estado Novo (1931-1948), Lisboa, Editorial Estampa, 1999. 
ROCHA, Idorindo Vasconcelos da, O carvão numa economia nacional. $O$ caso das Minas do Pejão, Porto, 1997 (policopiado).

RODRIGUES JUNIOR, Manuel, $A$ indústria mineira em Portugal. Estudo económico e jurídico, Coimbra, Coimbra Editora, 1921.

RODRIGUES, Maria de Lurdes, Os engenheiros em Portugal: profissionalização e protagonismo, Oeiras, Celta Editora, 1999.

ROSAS, Fernando, O Estado Novo nos anos trinta (1939-1945), Lisboa, Editorial Estampa, 1986.

ROSAS, Fernando, Portugal entre a paz e a guerra (1928-1938), Lisboa, Editorial Estampa, 1990.

ROSAS, Fernando, Salazarismo e fomento económico, Lisboa, Editorial Notícias, 2000. Rumores subterrâneos, Mina de S. Domingos, s.e., 1929.

SÁ, Vitor, Roteiro da imprensa operária e sindical (1836-1986), Lisboa, Editorial Caminho, 1991.

SILVA, José Augusto do Espírito Santo da, Ordem e estratificação social em Cabeço do Pião (Minas da Panasqueira, 1940-1945 e 1960-1965), Lisboa, 1996 (policopiado).

SOLA, Luís de Castro e, $O$ estudo e aproveitamento do subsolo português. Conferência, Lisboa, s.e., 1934.

TELO, António José, Portugal na Segunda Guerra (;941-1945), 2 volumes, Lisboa, Editorial Vega, 1991.

TELO, António José, A neutralidade portuguesa e o ouro nazi, Lisboa, MNE/Quetzal Editores, 2000a.

TELO, António José e TORRE GÓMEZ, Hipólito de la, Portugal e Espanha nos sistemas internacionais contemporâneos, Lisboa, Edições Cosmos, 2000b.

VALÉRIO, Nuno e NUNES, Ana Bela, O crescimento económico moderno, Lisboa, Editorial Presença, 1995.

VILAR, António, O volfrâmio de Arouca. No contexto da Segunda Guerra Mundial (1939-1945), Arouca, CMA, 1998.

VITORINO, Francisco, "Agricultura e mineração, uma coexistência difícil. As Minas do Vale do Vouga e as comunidades do vale rio Águeda (1889-1924)", Gestão e Desenvolvimento, $\mathrm{n}^{\circ}$ 9, 2000, p. 255-299.

VITORINO, Francisco, "Minas do Vale do Vouga (1885-1931). Desenvolvimento económico em conflitualidade sócio-política?, Coimbra, 2002 (policopiado). 